\title{
35. RIDGE-ARC COLLISION: TIMING AND DEFORMATION DETERMINED BY LEG 134 DRILLING, CENTRAL NEW HEBRIDES ISLAND ARC ${ }^{1}$
}

\author{
H. Gary Greene ${ }^{2}$ and Jean-Yves Collot ${ }^{3}$
}

\begin{abstract}
Ocean Drilling Program (ODP) Leg 134 was located in the central part of the New Hebrides Island Arc, in the Southwest Pacific. Here the d'Entrecasteaux Zone of ridges, the North d'Entrecasteaux Ridge and South d'Entrecasteaux Chain, is colliding with the arc. The region has a Neogene history of subduction polarity reversal, ridge-arc collision, and back-arc spreading.

The reasons for drilling in this region included the following: (1) to determine the differences in the style and time scale of deformation associated with the two ridge-like features (a fairly continuous ridge and an irregularly topographic seamount chain) that are colliding with the central New Hebrides Island Arc; (2) to document the evolution of the magmatic arc in relation to the collision process and possible Neogene reversal of subduction; and (3) to understand the process of dewatering of a small accretionary wedge associated with ridge collision and subduction. Seven sites were occupied during the leg, five (Sites 827-831) were located in the d'Entrecasteaux Zone where collision is active. Three sites (Sites 827, 828, and 829) were located where the North d'Entrecasteaux Ridge is colliding, whereas two sites (Sites 830 and 831) were located in the South d'Entrecasteaux Chain collision zone. Sites 828 (on North d'Entrecasteaux Ridge) and 831 (on Bougainville Guyot) were located on the Pacific Plate, whereas all other sites were located on a microplate of the North Fiji Basin. Two sites (Sites 832 and 831) were located in the intra-arc North Aoba Basin.

Results of Leg 134 drilling showed that forearc deformation associated with the North d'Entrecasteaux Ridge and South d'Entrecasteaux Chain collision is distinct and different. The d'Entrecasteaux Zone is an Eocene subduction/obduction complex with a distinct submerged island arc. Collision and subduction of the North d'Entrecasteaux Ridge results in offscraping of ridge material and plating of the forearc with thrust sheets (flakes) as well as distinct forearc uplift. Some offscraped sedimentary rocks and surficial volcanic basement rocks of the North d'Entrecasteaux Ridge are being underplated to the New Hebrides Island forearc. In contrast, the South d'Entrecasteaux Chain is a serrated feature resulting in intermittent collision and subduction of seamounts. The collision of the Bougainville Guyot has indented the forearc and appears to be causing shortening through thrust faulting.

In addition, we found that the Quaternary relative convergence rate between the New Hebrides Island Arc at the latitude of Espiritu Santo Island is as high as 14 to $16 \mathrm{~cm} / \mathrm{yr}$. The northward migration rate of the d'Entrecasteaux Zone was found the be $\sim 2$ to $4 \mathrm{~cm} / \mathrm{yr}$ based on the newly determined Quaternary relative convergence rate. Using these rates we established the timing of initial d'Entrecasteaux Zone collision with the arc at $\sim 3 \mathrm{Ma}$ at the latitude of Epi Island and fixed the impact of the North d'Entrecasteaux Ridge upon Espiritu Santo Island at early Pleistocene (between 1.89 and $1.58 \mathrm{Ma}$ ).

Dewatering is occurring in the North d'Entrecasteaux Ridge accretionary wedge, and the wedge is dryer than other previously studied accretionary wedges, such as Barbados. This could be the result of less sediment being subducted at the New Hebrides compared to the Barbados.
\end{abstract}

\section{INTRODUCTION}

The New Hebrides Island Arc is located in the southwest Pacific, southeast of the Solomon Islands, due west of Fiji and east of Australia and New Caledonia (Fig. 1). It is an active volcanic island arc with present-day volcanism the result of east-to-west subduction of the Australia-India Plate beneath the Pacific Plate. The central part of the arc is composed of three distinct island chains of different ages, while the other parts of the arc exhibit a single active volcanic chain (Fig. 2). The oldest islands (Malakula, Espiritu Santo, and the Torres Group) are those of the Western Belt where the oldest exposed volcanic rocks are Oligocene to early Miocene. Lower Miocene to lower Pliocene volcanic rocks exposed on the islands of the Eastern Belt (Pentecost and Maewo) indicate that this island chain formed after the Western Belt islands and before the active Central Chain (Fig. 2). Separating the Western and Eastern belts of islands are two deep $(\sim 3 \mathrm{~km})$ intra-arc basins known as the Central (Aoba) basins. The Central Chain volcanic island of Aoba separates the North Aoba Basin from the South Aoba Basin. In this region the Central Chain islands of Ambrym, Aoba, and

\footnotetext{
${ }^{1}$ Greene, H.G., Collot, J.-Y., Stokking, L.B., et al., 1994. Proc. ODP, Sci. Results, 134: College Station, TX (Ocean Drilling Program)

${ }^{2}$ U.S. Geological Survey, Menlo Park, CA 94025, and Moss Landing Marine Laboratories, Moss Landing, CA 95039.

${ }^{3}$ ORSTOM, Villefranche-sur-Mer, France.
}

Santa Maria are aligned along the central axis of the intra-arc basins and represent the most recent volcanic island building phase.

A short distance (100-150 km) west of the active volcanic Central Chain lies the New Hebrides Trench, a deep (6-7 km) trench separated into northern and southern segments (North and South New Hebrides trenches) by the d'Entrecasteaux Zone (DEZ) of ridges and seamounts offshore of the island of Espiritu Santo. Here, the DEZ clogs the trench and no physiographic expression of the trench can be seen in the bathymetry. The DEZ is an arcuate topographic high (2-4 $\mathrm{km}$ high) composed of the North d'Entrecasteaux Ridge (NDR) and the South d'Entrecasteaux Chain (SDC) separated by basins and troughs. To the west, the NDR curves south to connect with the New Caledonia Ridge and the SDC curves south to connect with the Loyalty Ridge. The DEZ is proposed to be an early Eocene island arc and subduction complex (Daniel et al., 1977; Weissel et al., 1982; Maillet et al., 1983).

The backarc of the New Hebrides Island Arc is continuous with, and part of, the North Fiji Basin, which is composed of several microplates separated by active spreading centers and fracture zones (Auzende et al., 1988). The northern boundary of the North Fiji Basin is defined by the Vitiaz trench, a fossil subduction zone (Kroenke, 1984).

Present day relative convergence rate at the latitude of southern Espiritu Santo is 14-16 cm/yr (Taylor et al., this volume). Collision of the DEZ is causing uplift of Espiritu Santo (Taylor et al., 1980, $1987)$ and has caused significant deformation across the arc (Collot and Fisher, 1988; Greene, Macfarlane, Johnson, and Crawford, 1988; 


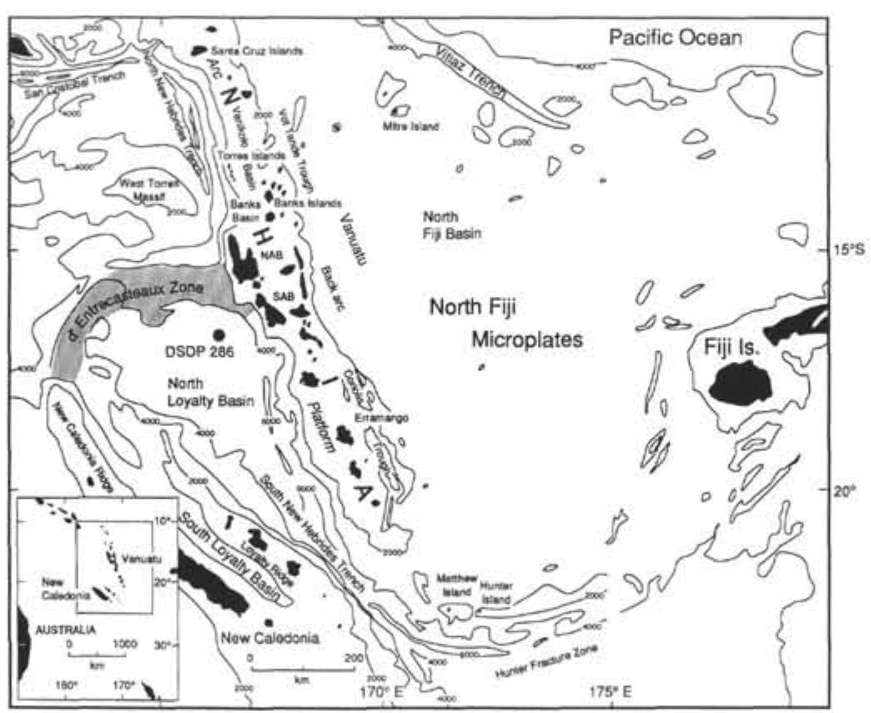

Figure 1. Regional bathymetry (in meters) and island distribution in the southwest Pacific. NAB $=$ North Aoba Basin; $\mathrm{SAB}=$ South Aoba Basin; NHIA $=$ New Hebrides Island Arc $;$ DSDP $=$ Deep Sea Drilling Project $($ modified from Kroenke et al., 1983).

Daniel et al., 1989). Because of the arcuate nature of the DEZ and the nearly orthogonal plate motion where the collision is taking place, the DEZ today is subducting along a trend of $N 75^{\circ} \pm 11^{\circ} \mathrm{E}$ with respect to the Pacific Plate and the New Hebrides Island Arc located on one of the microplates of the North Fiji Basin (Pascal et al., 1978) and is migrating northward along the arc at a rate of $2-4 \mathrm{~cm} / \mathrm{yr}$ (Taylor et al., this volume; Greene et al., this volume). This northward migration has deformed the forearc (Fisher, 1986) producing areas of (1) compression in front of the NDR; (2) forearc uplift at the point of collision; and (3) extension in the wake of the NDR (Collot and Fisher, 1991). Significant $(\sim 10 \mathrm{~km})$ indentation of the forearc has occurred where the Bougainville Guyot, located at the eastern end of the SDC, is colliding with the New Hebrides Island Arc. Across-arc deformation associated with the collision of the DEZ is illustrated in the leaky transverse fracture zones that appear to be conduits for the construction of the volcanic islands of Ambrym, Aoba, and Santa Maria, where primitive picritic lavas are found (Crawford et al., 1988; Greene, Macfarlane, Johnson, and Crawford, 1988). In addition, no back-arc troughs adjacent to the Central Basins area are observed, whereas to the north and south the Vot Tande and Coriolis back-arc troughs are present (Karig and Mammerickx, 1972; Dubois et al., 1975, 1978; Recy et al., 1986 , 1990; Charvis and Pelletier, 1989). Compressional structures such as folds and faults along the northwestern flank (Daniel et al., 1989) and a large thrust fault along the eastern flank of Maewo (Tiffin et al., 1990; Price et al., 1993) appear to substantiate across-arc deformation along a deep-seated horizontal plane.

\section{Origin of the Island Arc and Intra-arc Basins}

Two major hypotheses have been presented to explain the origin of the New Hebrides Island Arc. One hypothesis explains the formation of the various island belts in the central part of the arc as being produced by the subduction of an east-dipping slab that changed inclination through time (Luyendyk et al., 1974; Carney and Macfarlane, 1977; Hanus and Vanek, 1983; Katz, 1988; Louat et al., 1988). Periodic cessation of subduction, with breaking off of the downgoing slab and shifting from a fairly steeply dipping Wadati-Benioff zone to a shallower one and back again, is proposed to explain the west-to-east and subsequent east-to-west migration of the volcanic axis through time within the Central Basins region of the arc.

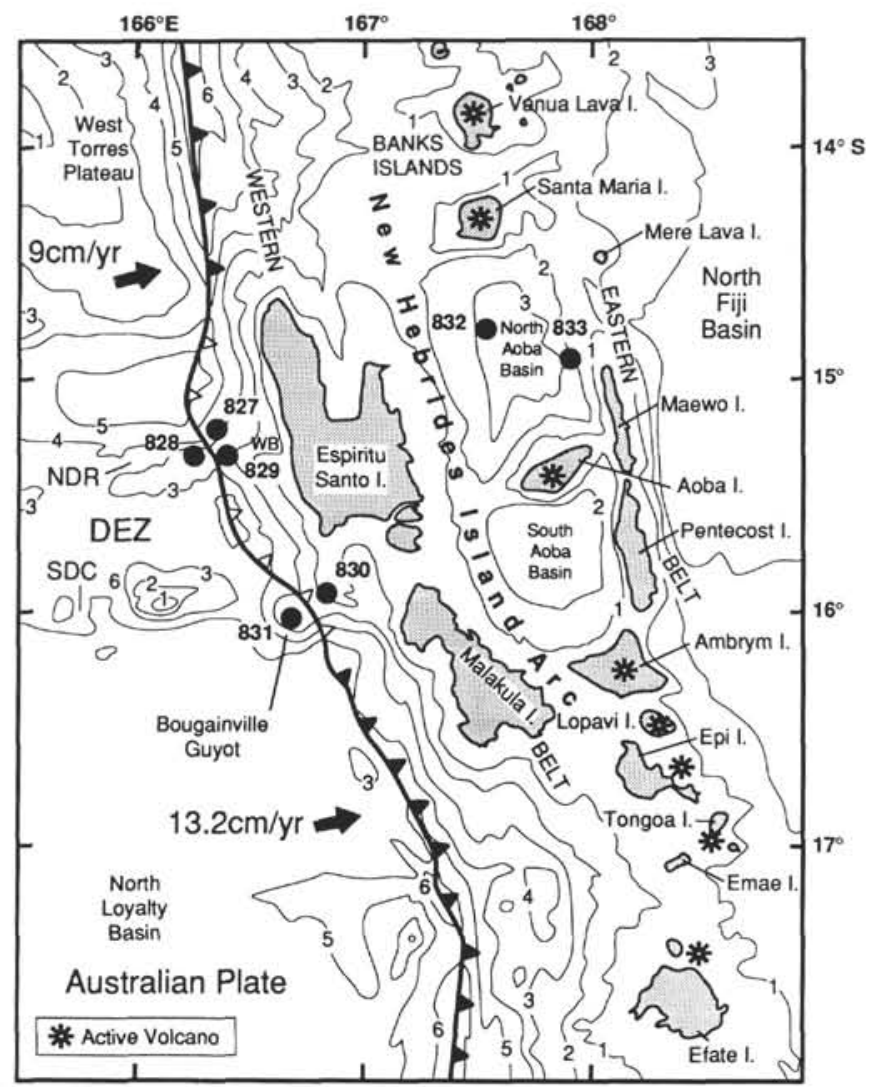

Figure 2. Map showing physiographic features and Leg 134 drilling sites (large dots) in the central New Hebrides Island Arc area. Large asterisks indicate active volcanoes. Barbed heavy line shows trace of subduction zone; barbs on upper plates, open barbs where trench is clogged by collision of DEZ. Bathymetry in kilometers.

The preferred alternative hypothesis explains the formation of multiple island belts by reversal of subduction polarity (Chase, 1971; Karig and Mammerickx, 1972; Gill and Gorton, 1973; Carney and Macfarlane, 1978; Kroenke, 1984; Falvey and Greene, 1988). This hypothesis states that late Eocene southward subduction of the Pacific Plate beneath the Australia-India Plate at the Vitiaz Trench formed the Western Belt. The late Eocene New Hebrides Island Arc was part of a continuous island arc that included the Tonga and the Solomon islands arc, located above a southwest-dipping subduction zone. A later relocation of the plate boundary to a position south of the Vitiaz arc, and a middle Miocene reversal in subduction direction, were accompanied by spreading and opening of the North Fiji Basin. This event and subduction flip initiated southwestward migration of spreading to the New Hebrides backarc, with the New Hebrides Island Arc south of Erromango moving away (westward) from Fiji. Later ( 3.5 Ma), the spreading center propagated into the northwestern corner of the northern (north of Erromango) part of the arc (Musgrave and Firth, 1993). When the Australia-India Plate began to subduct beneath the Pacific Plate, the Eastern Belt and Central Chain islands began to form (Chase, 1971; Carney and Macfarlane, 1978, 1980; Kroenke, 1984; Macfarlane et al., 1988).

\section{Drilling Objectives}

Objectives of the Ocean Drilling Program (ODP) Leg 134 in the central New Hebrides Island Arc focused on three important and poorly understood tectonic processes that occur along aseismic ridgeisland arc collision zones. We sought to (1) determine the differences 
in the style and time scale of deformation associated with two different types of positive topographic features (a fairly continuous smooth ridge and a more serrated, irregular seamount chain) that are colliding with the central New Hebrides Island Arc; (2) document the evolution of the magmatic arc in relation to the collision process and possible Neogene reversal of subduction; and (3) understand the process of dewatering of a small accretionary wedge associated with ridge collision and subduction. Five of the seven sites were occupied in the collision zone: two (Sites 828 and 831) were located on the Australian Plate (Fig. 2) and three (Sites 827, 829, and 830) were located on the forearc slope (Fig. 3). The remaining sites were located in the intraarc North Aoba Basin. This synthesis of drilling results is divided into arc-ridge collision and intra-arc basin areas. This paper briefly describes the results of Leg 134 drilling in relation to these objectives.

\section{RESULTS}

Drilling revealed the following: (1) significant differences in forearc deformation associated with the collision of the NDR and the SDC; (2) evidence for timing of the DEZ collision and opening of the North Fiji Basin, and constraining the Quaternary relative plate motion along the western Australia-India Plate; and (3) similarities and differences in dewatering of a small collisional accretionary wedge compared to much larger wedges such as that found in Barbados. In the intra-arc North Aoba Basin drilling was aimed at determining intra-arc basin formation and timing of DEZ collision based on dating an unconformity identified from seismic reflection profiles that appeared to reflect uplift of Espiritu Santo Island, possibly from the collision of the DEZ. In addition, it was hoped that the deep stratigraphy of the North Aoba Basin would reveal evidence to document middle Miocene subduction polarity reversal. However, no conclusive evidence for (or against) subduction polarity reversal in middle Miocene was identified from the drilling data.

\section{DEZ Collision Zone}

The DEZ is a fairly continuous arcuate ridge system raising 2 to 4 $\mathrm{km}$ above the flat abyssal plain of the Australia-India Plate; it is over $100 \mathrm{~km}$ wide and extends for over $600 \mathrm{~km}$ from New Caledonia to Vanuatu. Seafloor sampling along the DEZ west of $166^{\circ} 00^{\prime} \mathrm{E}$ (Maillet et al., 1983) and drilling in the New Caledonia Basin (Shipboard Scientific Party, 1975) 75 km southeast of Sabine Bank of the SDC yielded data upon which tectonic speculations were based prior to Leg 134. Dredge samples taken along the DEZ indicate that basement rocks of the NDR are similar to mid-ocean ridge basalts (MORB); fissiontrack ages of these rocks ranged from 56-36 Ma (Eocene to Oligocene). Maillet et al. (1983) proposed that the morphology of the DEZ originated from extensional horst-and-graben tectonics, resulting in uplift and exposure of ocean-floor basement rocks. Collot et al. (1985) concluded that the eastern DEZ may be a pre-Miocene south-dipping subduction zone. Burne et al. (1988), whose data support the hypothesis of Maillet et al. (1983), state that the NDR consists of 37 Ma ocean floor uplifted during the middle Miocene, and further suggest that the SDC represents the remnants of an Eocene proto-island arc formed contemporaneously with subduction along the northern margin of the DEZ. Wells (1989) suggested that the DEZ was once continuous with the Solomons and Pocklington trough Eocene arcs and was deformed by late Eocene collision of oceanic plateaus (Louisiade and Torres) to form present east-west trend of DEZ before subduction jumped to the Vitiaz Trench.

Impingement of the DEZ against the arc has greatly altered the arc's morphology and structure (Greene, Macfarlane, Johnson, and Crawford, 1988; Collot and Fisher, 1991). Drilling indicated that each of the topographic highs of the DEZ causes different forearc deformation. The sedimentary and surficial basement rocks of the NDR, whose basement rocks are MORB, have been scraped off and accreted to the forearc during subduction. This accretion has formed the

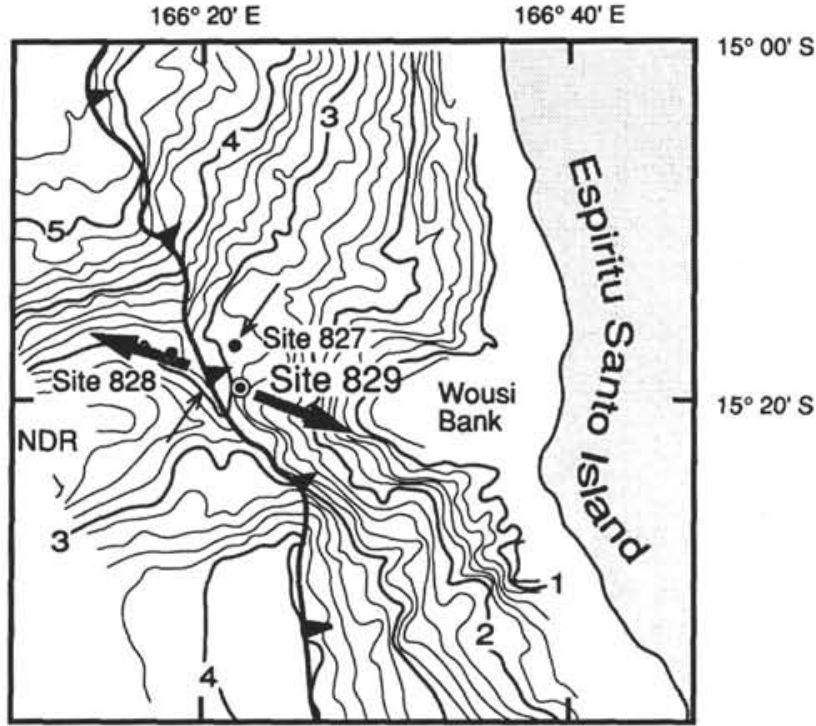

Figure 3. Map showing location of Leg 134 Sites 827,828 , and 829 where the North d'Entrecasteaux Ridge (NDR) is colliding with the New Hebrides Island Arc. Heavy barbed line shows seafloor trace of subduction zone. Arrows show direction of borehole elongation based on BHTV data (Krammer et al., this volume), which lie perpendicular to the compression stress orientation (light arrows) as determined from borehole breakout studies (Chabernaud, this volume).

Wousi Bank, which consists of uplifted forearc rocks and stacked thrust sheets. The SDC impacts the forearc in a different manner: little deformation has occurred compared to the NDR collision zone, although the SDC is converging at the same rate and at the same angle as the NDR.

Major compositional changes of pore fluids in the collision zone result from diagenetic alteration of volcanic sediment, and they (deep fluids at Site 829) are manifested as chloride greater and less than seawater values, calcium concentrations greater than seawater values, and sodium, potassium, and magnesium concentrations lower than seawater values (Martin, this volume). Variations in these solute concentrations correspond to structural features, particularly across thrust faults penetrated at Site 829 , which implies that the faults may channelize fluid flow as they do in the Barbados accretionary wedge (Mascle, Moore, et al., 1988). Low chloride and high methane concentrations characterize fluids from deep levels at Site 829 , a covariance that also characterizes the pore fluid chemistry within the décollement at the Barbados accretionary wedge. Thus, the fluid near the deep thrust fault at Site 829 may have been derived from décollement and subduction-related processes.

\section{North d'Entrecasteaux Collision (Sites 827-829)}

Drilling sites (Fig. 2) located in the NDR-arc collision zone (Sites 827-829) document offscraping of NDR sediment cover and surficial volcanic basement rocks. Thus, drilling results from Site 828 support the interpretations of Maillet et al. (1983), Collot et al. (1985), and Burne et al. (1988). Fractionated N-MORB lavas composed of plagioclase-clinopyroxene-phyric basalts were recovered at Site 828 on the NDR (Coltorti et al., this volume). These basalts show picritic tendency and Coltorti et al. (this volume) describe these rocks as from a mantle source modified by subduction-related geochemical components that are intermediate between MORB and island arc tholeiites (IAT), resembling magmas from a small intraoceanic back-arc basin, or back-arc basin basalts (BABB). With respect to the DEZ, these authors state that at least the eastern part of the NDR appears to be related to an Eocene to Oligocene subduction complex that lies in the 

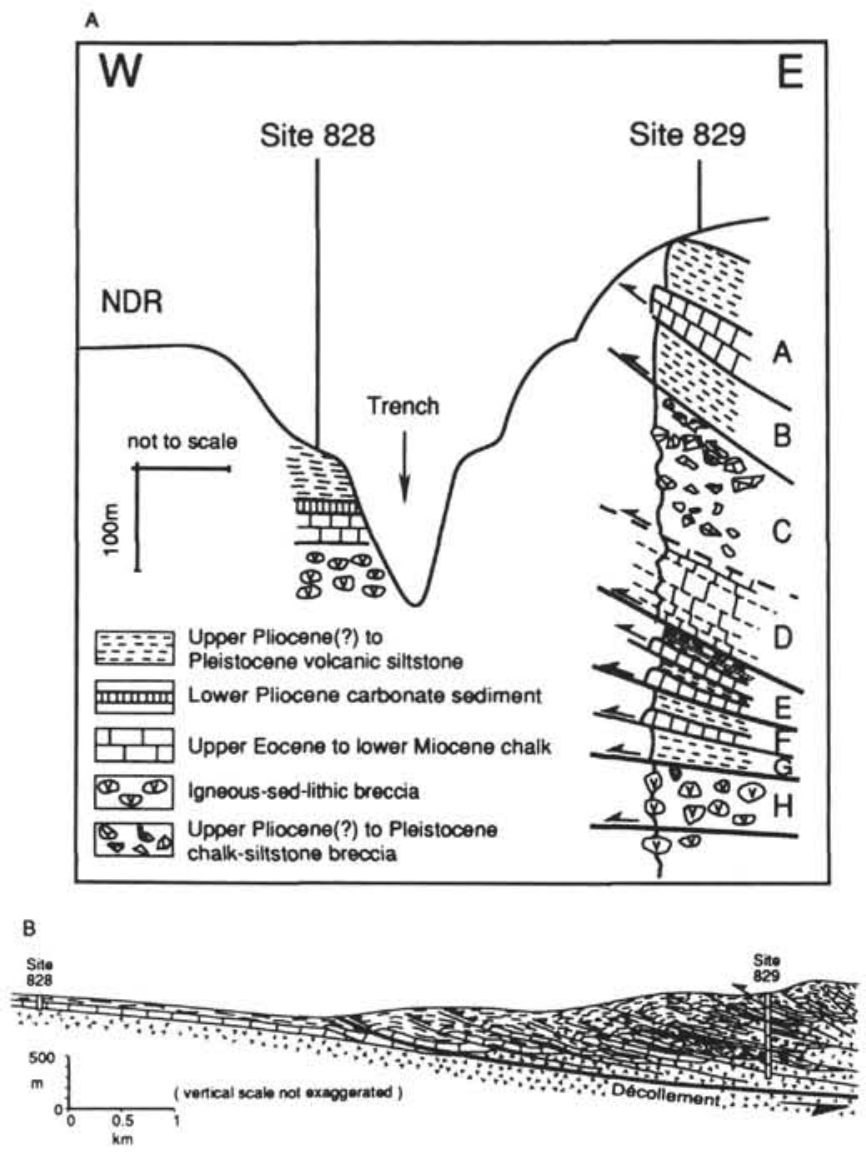

Figure 4. Schematic representation of accreted material in the NDR-New Hebrides Island Arc collision zone. A. Relationship of NDR (Site 828) stratigraphy with forearc (Site 829) stratigraphy. B. Detail sketch of accretionary wedge (modified from Meschede and Pelletier, this volume).

forearc of a volcanic island arc represented by the SDC. Based on the coexistence of MORB and BABB rocks, rocks that are usually found in spreading centers behind active volcanic arcs, Coltorti et al. (this volume) speculate that this material represents accretion of back-arc rocks from a previous spreading event.

The tectonic history of the DEZ is partially recorded in the sediment drilled on the ridges during Leg 134 (Fig. 3). At Site 828 on the NDR a 91-m-thick late Eocene to Pleistocene marine sedimentary sequence unconformably overlies a subaerially altered basement surface. Including the basement unconformity, two prominent and one questionable unconformities (at 61.9, 69.3, and 90.8 meters below seafloor [mbsf]) interrupt the sequence. These unconformities bound lithologic units that vary considerably in lithology and age. All of the unconformities are restricted to the lower part of the sedimentary sequence, beneath $58 \mathrm{mbsf}$.

A nannofossil chalk of late Eocene to late Oligocene age sits directly upon a highly weathered red to greenish volcanic breccia. Some confusion lies in the age of the basal part of the nannofossil chalk as foraminifers indicate a late to middle Oligocene age (P18/19) whereas nannofossils observed in Hole $828 \mathrm{~B}$ contain an Eocene assemblage (NP20) that suggests the older age (Staerker, this volume). This lowermost subtle unconformity is based on nannofossil analysis and indicates that uppermost Eocene strata are missing (CP-16 juxtaposed with CP-15a; Staerker, this volume). However, Roperch et al. (this volume) state that magnetostratigraphy favors deposition during the Oligocene (30-36 Ma). These authors, based on paleomagnetic analyses of the Oligocene sediments, report a paleolatitude for Site 828 in Oligocene to be $20.9^{\circ} \mathrm{S}$, about $10^{\circ}$ farther north than the expected latitude based on hot-spot reconstruction model.

A large hiatus exists at the middle unconformity where uppermost Oligocene, Miocene, and lowermost Pliocene are missing (Staerker, this volume). The uppermost unconformity has an upper Pliocene to lower Pleistocene hiatus (Staerker, this volume).

During the Eocene, volcanic breccia and lava flows built up the flank of the NDR at Site 828 where the highly oxidized, subaerially weathered volcanic rubble was drilled. Subsidence of the ridge then occurred, followed by the deposition of over $21.5 \mathrm{~m}$ of pelagic nannofossil ooze during early to late Oligocene ( 7-12 m.y.). This was a time of low deposition rate as indicated by an $\sim 5 \mathrm{~mm} / \mathrm{yr}$ average sediment accumulation rate and the presence of small manganese nodules found in the unit above basement. One Fe-Mn nodule was analyzed and found to contain predominately manganese oxides with minor detrital quartz and plagioclase with a chemistry and mineralogy typical of hydrogenetic (precipitated from cold ambient seawater) Mn precipitation with little evidence of hydrothermal or diagenetic input. This indicates that the nodule is associated more with a seamount than with an abyssal plain (J. R. Hein, pers. comm., 1992). Sometime between the late Oligocene and late Miocene probable uplifts and perhaps even emergence, of the NDR took place causing an 18 m.y. hiatus through complete removal or nondeposition of sediment.

Subsidence with subsequent slow deposition of foraminiferal ooze occurred during the late Miocene to early Pliocene. This unconsolidated, highly permeable unit evidently was extensively compressed, dewatered, and consolidated into chalk during subduction as indicated by Miocene chalk found in the forearc holes (Sites 827 and 828 ). Sometime during the Pliocene, either sea-level fell or uplift may have once again occurred, perhaps in association with the arrival of the present eastern terminus of the NDR, including the location of Site 828 , at the outer lithospheric bulge, causing erosion or preventing deposition to produce an uppermost hiatus of 3 to $5 \mathrm{~m}$.y. Martinez (this volume) found that the dissolution records of the last $250 \mathrm{ky}$ at both Sites 828 and 832 are similar to those of the Ontong Java Plateau.

Sedimentation rates along the eastern part of the NDR during the Pleistocene increased considerably to $\sim 60 \mathrm{~m} / \mathrm{m}$.y. with the influx of volcanic silts and ash. This was most likely in response to the convergence of the ridge, including Site 828 , with the New Hebrides Island Arc. Sedimentation was influenced both by ash fall and hemipelagic contribution from the active volcanoes of the island arc. Geochemical analyses of some of the Pleistocene ashes indicate that they originated from explosive events associated with the volcanically active Central Chain, some $150 \mathrm{~km}$ to the southeast (Collot, Greene, Stokking, et al., 1992). Site 828 is about to be subducted beneath the forearc of the central New Hebrides Island Arc and appears to be undergoing initial tensional faulting in response to the bending of the lithosphere in this area.

\section{Offscraping}

At least nine thrust sheets (all less than $120 \mathrm{~m}$ thick) were drilled at Site 829 (Fig. 4) and consist of alternating Oligocene to lower Miocene chalks and Pliocene to Pleistocene volcanic siltstone (Collot, Greene, Stokking, et al., 1992; Reid et al., this volume; Pelletier et al., this volume; Collot et al., this volume). These thrust sheets were severely compressed, dewatered, and stacked like cards to form the bathymetric high known as Wousi Bank (Ask and Leonard, this volume; Leonard and Ask, this volume; Martin, this volume). Magnetic fabric studies of rocks in the accretionary wedge implies that deformation in the shear zones is accomplished primarily by motion along bedding planes, whereas materials within the beds themselves remain relatively competent (Stokking et al., this volume).

The timing of the uplift of Wousi Bank appears to be caused by the collision of the NDR, but is poorly constrained. The absence of con- 
glomerate in Units I and II at Hole 827B suggests that the source of coarse sediment from Espiritu Santo Island may have been diverted elsewhere by the uplift of Wousi Bank in late Pliocene or middle Pleistocene time (Reid et al., this volume; Perembo, this volume). The change from hemipelagic sedimentation to turbidites in Unit I suggests that a small basin or fan formed on the flank of Wousi Bank and trapped sediment transported downslope. This basin corresponds to the flat terrace on which Site 827 is located (Fig. 3). Paleomagnetic data indicate that the turbidites in the basin are younger than $0.7 \mathrm{Ma}$, and a nannofossil datum near the base of Unit I suggests that the basin could be as young as $0.11 \mathrm{Ma}$ (Collot, Greene, Stokking, et al., 1992). Therefore, the youngest NDR collision is occurring at Wousi Bank and started $0.7 \mathrm{Ma}$ or later.

\section{Dewatering}

Pore-fluid, physical properties, and structural data indicate that the collision between the NDR and the arc has compressed and dewatered the accreted sediment in the NDR-arc collision zone (Martin, this volume; Leonard and Ask, this volume; Ask and Leonard, this volume; Meschede and Pelletier, this volume). Drilling in the Barbados accretionary prism indicated that dewatering of the prism was concentrated along thrust faults and that fluids low in chloride and high in methane were concentrated along the décollement (Mascle, Moore, et al., 1988; Gieskes, Blanc, et al., 1990; Gieskes, Vrolijk, and Blanc, 1990). In Hole $829 \mathrm{~B}$ fluids appeared to be confined to several major thrust faults where $\mathrm{Cl}^{-}$concentrations were less than seawater and methane was detected (Martin, this volume). The fluid chemistry along some thrust zones in the New Hebrides forearc resemble those found along thrust faults of the Barbados accretionary wedge (Mascle, Moore, et al., 1988). However, the New Hebrides accretionary wedge thrusts are relatively dry when compared to other accretionary boundaries.

The concentration of fluids along some thrust faults as observed in the drill cores and the accumulation of precipitated carbonate-like deposits beneath thrust faults as observed from Nautile submersible dives suggest dewatering of the wedge along thrusts, although no mud volcanoes or cold seep communities are associated with the wedge (Greene et al., 1992). Brown clay at fault contacts suggests that pelagic and hemipelagic clays facilitate movement along thrust faults and may actually dictate where thrusting will take place (Reid et al., this volume; Leonard and Ask, this volume). In addition, Ask and Leonard (this volume) found that calcareous sediment drilled in the DEZ-arc collision zone contained more water than non-calcareous sediment.

Dewatering by compressional stress associated with tectonic accretion is suggested by lower water contents at Site 829 than in tectonically undisturbed sediment of equivalent lithology and depth at Site 828 . The upper $100 \mathrm{~m}$ at both sites consists of silt and chalk (firm ooze at Site 828), but water contents in the silt and chalk at Site 829 are about $40 \%$ and $28 \%$, compared to $50 \%$ and $55 \%$ in the silt and chalk-like rocks at Site 828 (Collot, Greene, Stokking, et al., 1992; Ask and Leonard, this volume). In addition, the unusually low fluid content at Site 829 , indicates that compression may be associated with the collision between the NDR and the island arc. Anomalously high concentrations of sulfate and methane in pore fluids at $510 \mathrm{mbsf}$ in Hole 829A suggest that thrust faults near this depth in the collision zone may be connected at depth to the décollement. Martin (this volume), however, finds no changes in pore-fluid chemistry in sections of tectonized sediment that would indicate a proto-décollement and the likely flow horizon for accretionary wedge fluids.

\section{Plating of Forearc with Offscraped Thrust Sheets (Flakes)}

The forearc slope of the New Hebrides Island Arc is composed of offscraped NDR materials in discrete thin thrust sheets. Greene et al. (this volume) and Collot et al. (this volume) speculate that the forearc slope is composed of stacked thrust sheets representative of the evolving forearc and the impact of the DEZ. Therefore, they proposed that the forearc slope from offshore Epi Island to central Espiritu Santo Island is composed of lenses, or "flakes," of accreted and distorted thrust sheets of Oligocene to lower Miocene chalks and Pliocene to Pleistocene volcanic siltstones (Fig. 5). According to seismic reflection data (Collot et al., this volume), these flakes would be on the order of 3 to $5 \mathrm{~km}$ wide and composed of imbricated thrust sheets approximately 300 to $500 \mathrm{~m}$ thick, which plate the forearc slope with shingled layers of thrust sheets.

\section{South d'Entrecasteaux Chain Collision (Sites 830-831)}

Just south of Espiritu Santo Island the SDC is colliding with the New Hebrides Island Arc. Here, Bougainville Guyot is a prominent topographic feature embedded in the forearc slope (Fig. 6).

Bougainville Guyot is a volcanic edifice capped with a thick $(\sim 700 \mathrm{~m})$, well-layered, flat carbonate sequence of lagoonal and coral reef deposits (Collot, Greene, Stokking, et al., 1992). Seismic-reflection and Seabeam bathymetric data along with observations and sampling during Nautile dives (Daniel et al., 1986; Collot et al., 1989; Fisher et al., 1986) show that several coral pinnacles are scattered about the flat, gently $\left(\sim 5^{\circ}\right)$ eastward-dipping summit platform. Local topographic highs along the periphery of the summit platform appear to be remnant fringing reefs. The edge of the summit platform is defined by steep scarps that are $\sim 700 \mathrm{~m}$ high whose base is at the smooth upper flank of the guyot. Fisher et al. (1991) describe the flanks of the guyot as a debris apron composed of carbonate and volcanic rocks that have been shed from the guyot by mass wasting.

The Bougainville Guyot impinges upon the forearc slope of the Central New Hebrides Island Arc, indents the forearc slope by $10 \mathrm{~km}$ and deforms the forearc as illustrated by an anticlinal dome and a series of imbricated thrust faults east of the impact zone (Fig. 6). Anomalous bathymetric features, such as a subcircular topographic reentrant in the forearc-slope east and south of the guyot, suggest that other seamounts or guyots have previously been subducted.

Island-arc basalts, andesite, and middle Eocene to middle Oligocene sedimentary rocks, including carbonate rocks, have been recovered from the flanks of the Bougainville Guyot (Collot et al., 1992). This guyot, like many of the conical seamounts and guyots of the SDC, is an andesitic seamount carried eastward upon the Australia-India Plate, which is converging with the central New Hebrides Island Arc at about $14-16 \mathrm{~cm} / \mathrm{yr}$ (Taylor et al., this volume). While being carried along on the Australia-India Plate, the Bougainville Guyot was uplifted as it approached the New Hebrides Island Arc and emerged on the outer rise before sliding down the subduction zone (Dubois et al., 1988; Collot, Greene, Stokking, et al., 1992). The guyot is now in active collision with the arc and at least one third of the guyot is interpreted to have broken off at the eastern edge and buried beneath the forearc slope (Fisher et al., 1991). The guyot is either being subducted beneath the arc or obducted onto the forearc slope.

During the Eocene or later, late-stage volcanic eruptions completed the building of the submarine edifice or island that has become the Bougainville Guyot (Baker et al., this volume). Andesitic breccias were emplaced as pillow lavas and associated hyaloclasts. Chilled margins or coronas around the clasts of the breccia suggest that miniature pillows developed during quenching in seawater. More vesicular fragments suggest a shallow-water origin, and perhaps the input of subaerial material from an island source. Maximum depth of deposition during the late volcanic stage is estimated to be a few hundred meters. The wispy shapes of blebs suggest that the magma was still reasonably fluid or plastic at the time of deposition. Deposition of these volcanic rocks probably formed an apron around the submarine volcano with some of the more chaotic breccias being deposited by avalanches or debris flows. Petrographic characteristics of two-pyroxene andesites show calc-alkaline or island-arc tholeiite affinity, indicating that the guyot is unequivocally of island-arc origin. A K-Ar date from basement rocks drilled at the Bougainville Guyot is $37 \pm 1.0 \mathrm{Ma}$ (Rex, this volume). This age and the geochemical data support the premise of an 
N.

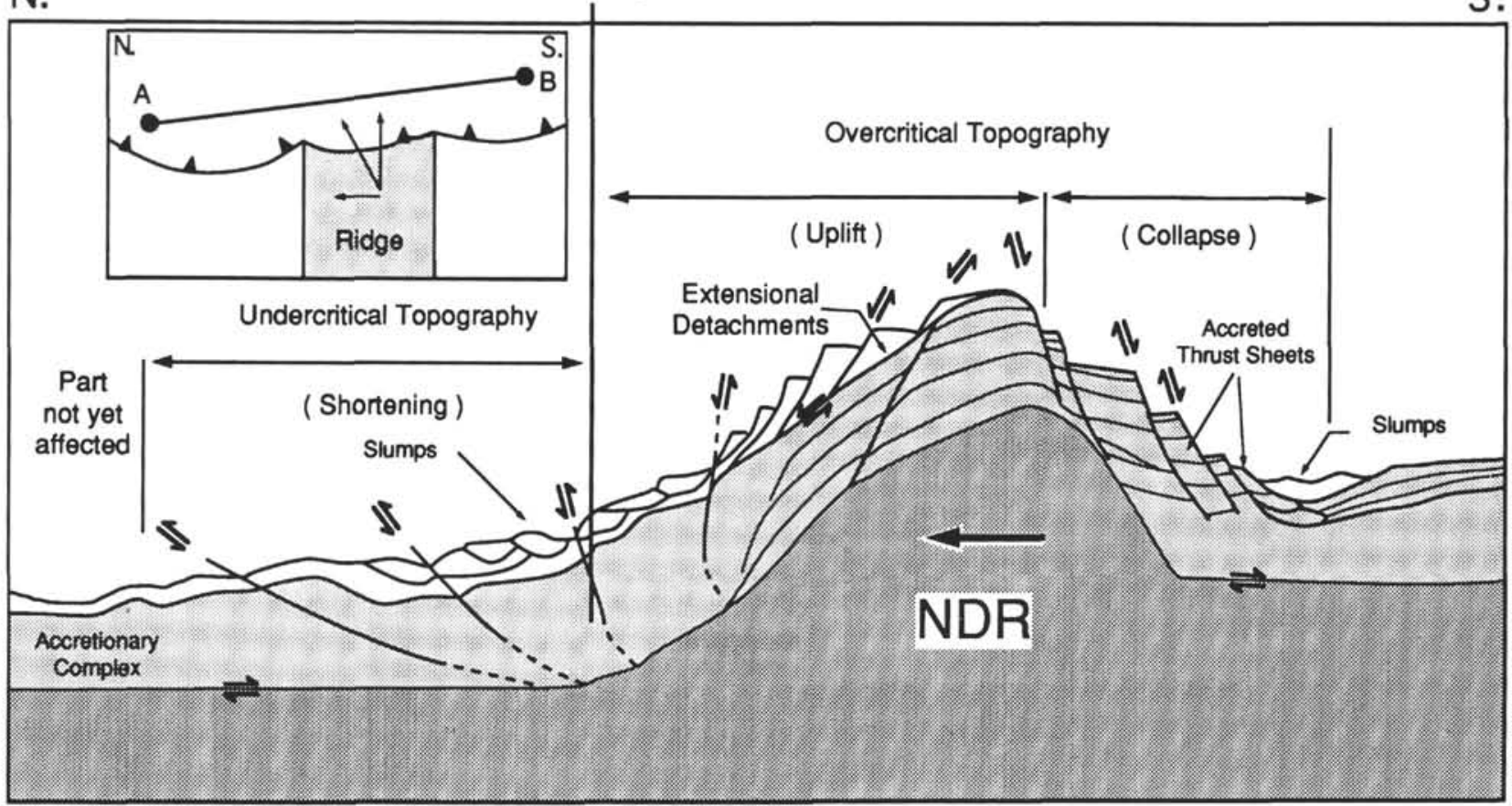

Figure 5. Conceptual model of North d'Entrecasteaux Ridge (NDR) obliquely subducting beneath the New Hebrides Island Arc and showing accumulation and distortion of NDR material ("flakes") being deposited in the wake of the northward migration of the NDR (modified from Collot and Fisher, 1991).

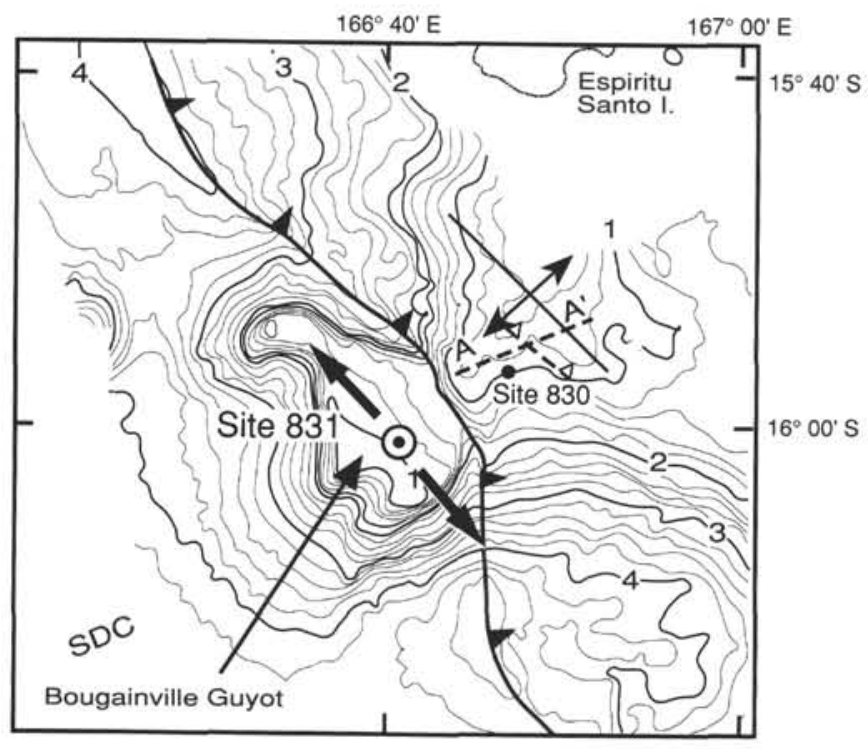

Figure 6. Map showing location of Leg 134 Sites 830 and 831 where the South d'Entrecasteaux Chain (SDC) is colliding with the New Hebrides Island Arc. Heavy barbed line shows seafloor trace of subduction zone and heavy arrows indicate borehole elongation based on BHTV data (Krammer, this volume), which lies nearly perpendicular to convergence direction. Heavy dashed lines with open barbs indicate approximate seafloor trace of thrust seen in seismic reflection profiles (Fisher et al., this volume). Bathymetric contours at $200 \mathrm{~m}$ intervals, numbers indicate depth in kilometers.

Eocene proto-island arc associated with a southward-dipping subduction zone (Maillet et al., 1983; Burne et al., 1988).

The oxidized andesitic rocks of the guyot indicate that the guyot was probably an island before subsidence during the late Oligocene, when it started accumulating the $727.5 \mathrm{~m}$ of carbonate rocks. Neritic carbonate sediments were deposited from the Oligocene to early
Miocene, and at least two episodes of emergence, as indicated by the soil horizons at 688.1 and $707.6 \mathrm{mbsf}$ (Fig. 7), occurred during this time. No middle to upper Miocene sediments were identified; the possible absence of these sediments at this site is consistent with a major Miocene hiatus similar to that observed at Site 828 and at Deep Sea Drilling Project (DSDP) Site 286 (Shipboard Scientific Party, 1975). This hiatus may coincide with a facies change in a neritic carbonate sequence of the guyot at $529.6 \mathrm{mbsf}$; a coral- and foraminiferal-rich facies (429.6-727.5 mbsf). The Pliocene to Pleistocene neritic carbonates represent lagoonal sediment associated with an atoll. Eastward transport of the guyot upon the Australia-India Plate is documented by its submergence/emergence history (Taylor et al., this volume). As the guyot approached the outer rise of the New Hebrides Island Arc, it became quite shallow, similar to the condition that Sabine Bank is experiencing today (Dubois et al., 1988). During the late Pliocene $(\sim 2 \mathrm{Ma})$ or early Pleistocene, the shallow-water carbonate platform drowned, as indicated by the foraminiferal assemblage recovered from $30 \mathrm{mbsf}$. Major subsidence or sea-level rise and pelagic sedimentation occurred throughout the Pleistocene, as indicated by the foraminiferal assemblages examined from 20 to $4.5 \mathrm{mbsf}$ (Staerker, this volume). Ash layers found within the pelagic sediment between 0 and $15 \mathrm{mbsf}$ illustrate the influence of volcanic events along the Central Chain of the New Hebrides Island Arc on the guyot. Pelagic deposition and continued subsidence represent the transport of the guyot away from the outer rise and down the subduction zone to its present position on the forearc slope.

Strontium isotope and uranium series ages (Quinn et al., this volume) and a comparison of these dates to the vertical position (based on depth information) of the Bougainville Guyot as it passed over the outer rise of the New Hebrides Island Arc, indicate late Cenozoic convergence rate of the Australia-India Plate with the central New Hebrides Island Arc at $\sim 14-16 \mathrm{~cm} / \mathrm{yr}$ (Taylor et al., this volume). This is considerably higher ( $4-6 \mathrm{~cm} / \mathrm{yr}$ higher) than previously determined (American Association of Petroleum Geologists, 1985) suggesting that the Quaternary rate of opening of the North Fiji Basin is larger as well (Taylor et al., this volume). 


\section{Timing of Collision and Style of Arc Deformation}

Assuming that a substantial part (at least $250 \mathrm{~km}$ ) of the eastern DEZ has been subducted and that this subducted portion mimicked the present-day arcuate shape, Greene et al. (this volume) propose that the New Hebrides Island Arc first came into contact with the DEZ near the present location of Epi Island, sometime during the late Pliocene to early Pleistocene ( 1.5-3 Ma, using an average net convergence rate of $14-16 \mathrm{~cm} / \mathrm{yr}$ proposed by Taylor et al., this volume). Since that time, and because of the progressive clockwise rotation of the New Hebrides Island Arc and northwestward convergence of the Australian Plate, the arcuate DEZ has been migrating northward along a $250-\mathrm{km}$ expanse of forearc slope at a rate of between 3.2 and $4.1 \mathrm{~cm} / \mathrm{yr}$ (Taylor et al., this volume), leaving accreted NDR material (flakes) and deformed thrust sheets on the forearc slope (Fig. 5).

Deformation of the flakes plating the forearc, as proposed by Collot et al. (this volume) and Greene et al. (this volume), probably occur where seamounts of the SDC impinge upon the forearc slope. Docking or subduction of seamounts of the chain are structurally overprinting or eroding the offscraped materials from the NDR. In the area where the Bougainville Guyot is impacting the forearc slope, Greene et al. (this volume) speculate that previous deposited flakes are severely deformed and some are carried deep into the forearc with the leading edge of the guyot.

In addition to forearc plating and deformation, Greene, Macfarlane, Johnson, and Crawford (1988) state that transcurrent faults across the arc became the major structural pattern of the Central Basins area during Pliocene to Pleistocene time. The fracture zones allowed deep magma sources to form the islands of Ambrym and Aoba. Strikeslip displacement along faults in the fracture zones coincided with magma intrusion, and significant displacement (up to $25 \mathrm{~km}$ ) occurred along the fracture zones (Greene, Macfarlane, Johnson, and Crawford, 1988).

Because of the double ridge nature of the DEZ, material is first offscraped from the NDR and accreted to the forearc slope, followed by subsidence and mass wasting of the forearc as the ridge migrates to the north. Further deformation occurs with the collision of the SDC, which presently indents the forearc slope some $10 \mathrm{~km}$, creating severe mechanical stress that results in bedding plane thrust faults and forearc shortening.

Along the Western Belt, uplift (Taylor et al., 1985, 1987) and dilatational stresses in drill holes in the DEZ-arc collision zone indicate east-west compression (Figs. 3 and 6). Krammer and Chabernaud (this volume) state that borehole televiewer (BHTV) and Formation MicroScanner (FMS) data show preferred elongation (eastnortheast-west-southwest) in the boreholes. These authors show that a strong correlation with seafloor morphology and structural features exists in Hole $829 \mathrm{~A}$, formed by convergent compression $\left(\mathrm{N} 33^{\circ} \mathrm{E}\right.$, DEZ collision), and with the direction of plate convergence $\left(\mathrm{N} 58^{\circ} \mathrm{E}\right)$ in Hole 831B. Chabernaud (this volume) uses FMS data to show the imbricated structure of the thrust sheets in the accretionary complex. With compressional stress information inferred from breakout analyses and hydraulic fractures in holes of the North Aoba Basin, he shows east-northeast-west-southwest compression associated with latest Pliocene to Pleistocene uplift of the eastern flank of the basin.

\section{Intra-arc North Aoba Basin}

Gravity and seismic refraction data indicate that the North and South Aoba basins formed on 8- to 9-km-thick crust and furthermore that the igneous crust of the basins may have originated either as a trapped piece of oceanic crust or from island arc crustal thinning by extension (Collot and Fisher 1988). The North Aoba Basin was estimated to be filled with at least $5 \mathrm{~km}$ of sediment (Holmes, 1988). In the central part of the basin, seismic reflection profiles (Fisher et al., 1988; this volume; Greene and Johnson, 1988) do not show acoustic basement, and the depth of the basin cannot be determined from these

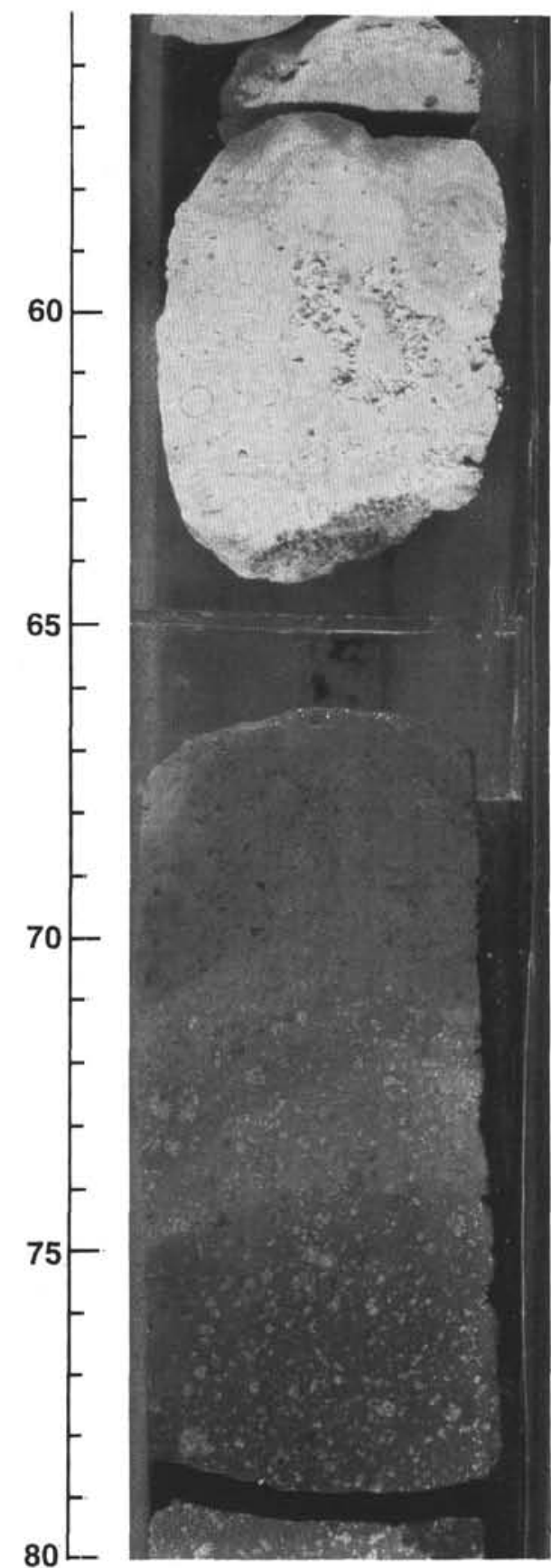

Figure 7. Photograph of Interval 134-831B-69R-1, $55-80 \mathrm{~cm}$, showing contact between overlying carbonate rocks (light) and weathered, oxidized volcanic basement surface (dark) at Bougainville Guyot.

data. However, Pontoise et al. (this volume) estimate a maximum thickness of about $4 \mathrm{~km}$, based on ocean-bottom seismograph refraction studies.

The collision of the DEZ has modified the Central Basins area, including the North Aoba Basin, dramatically as transcurrent motion divided the Central Basins through faulting transverse to the arc and extrusion of volcanic rocks at Aoba and Ambrym islands (Greene, Macfarlane, Johnson, and Crawford, 1988). This segmentation of the Central Basins appears to be the result of the collision of the DEZ with the New Hebrides Island Arc. The Ambrym and Aoba fracture zones have offset structural elements and allowed the intrusion of magma from depth (Fig. 8; Greene, Macfarlane, Johnson, and Crawford, 


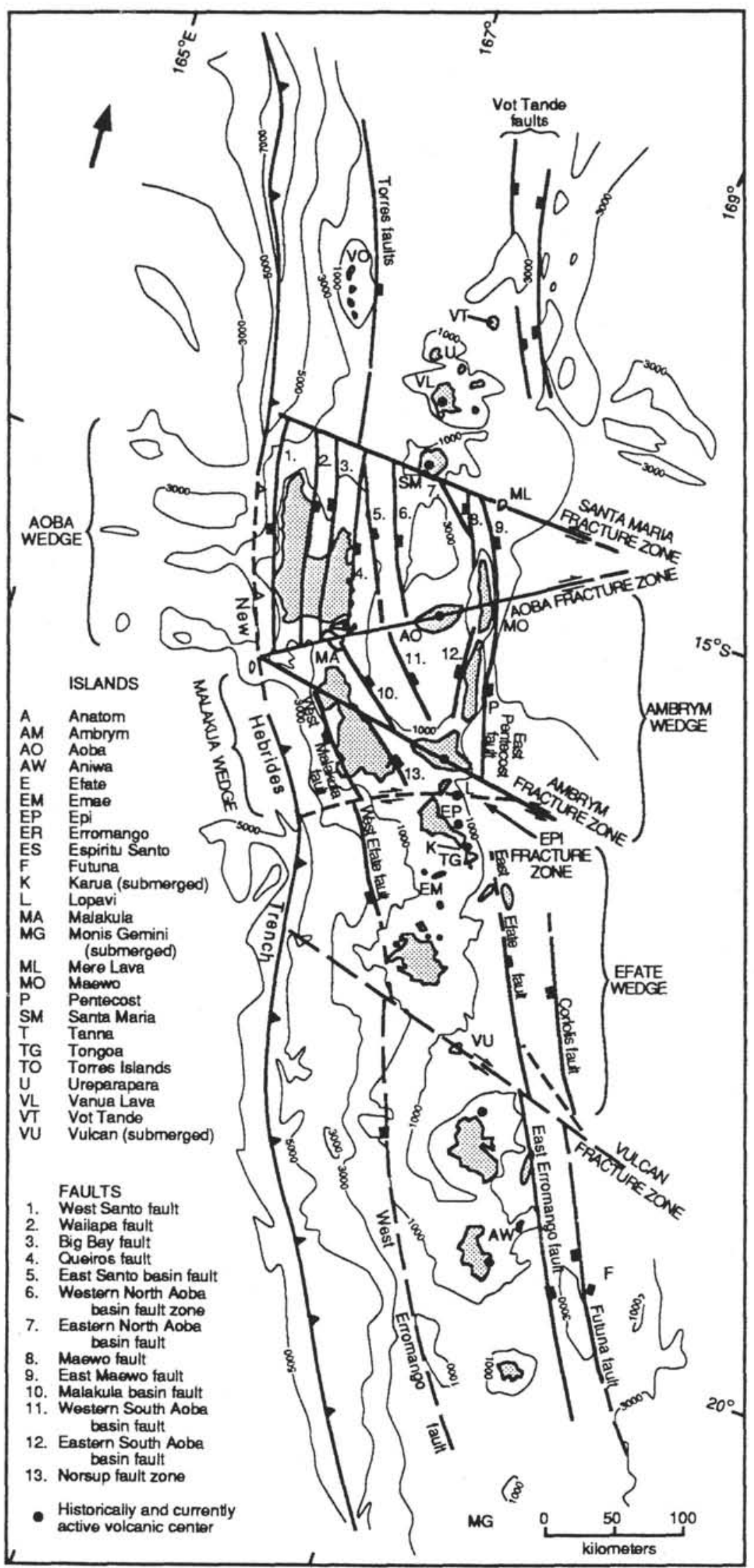

Figure 8. Major structural lineaments (faults and fracture zones), volcanic centers, and islands of the central New Hebrides Island Arc (Vanuatu). Faults dashed where inferred, volcanic centers (small dots); barbed lines same as in Figure 2. Structural blocks or "wedges" are indicated (modified from Greene, Macfarlane, and Wong, 1988). 
1988). The subdivision of the Central Basins appears to have started sometime after 1.0 to $1.8 \mathrm{Ma}$, when Ambrym and Aoba islands began to form as submarine edifices, based on the rate $(\sim 3-4 \mathrm{~cm} / \mathrm{yr})$ of DEZ northward migration defined by Taylor et al. (this volume).

Compressional focal mechanisms from earthquakes and westdipping slip vectors along the Eastern Belt (Collot et al., 1985; Louat and Pelletier, 1989) suggest that compressive stress is transmitted completely across the arc. Analyses of structural dilation, or tension, (Krammer et al., this volume) and stress from breakouts (Chabernaud, this volume) substantiate this conclusion (Fig. 9).

On the basis of dredge samples and correlation of acoustical units with island geology, the oldest rocks in the North Aoba Basin appear to be upper Oligocene to middle Miocene volcanic rocks (not penetrated at Sites 832 and 833) that underlie the west slope of the basin, and upper Miocene to upper Pliocene volcaniclastic graywacke and limestone (Fig. 10; Greene and Johnson, 1988; Johnson et al., 1988; Fisher et al., 1988; Collot, Greene, Stokking, et al., 1992; Fisher et al., this volume). Upper Pliocene or lower Pleistocene volcanic breccia and graywackes lap onto the east and west flanks of the basin. Middle Pleistocene silty limestone and foraminiferal chalk interbedded with volcanic sandstone and breccia overlie the late Pliocene or early Pleistocene sedimentary rocks. These rocks underlie Quaternary volcanic ash and pelagic sediment in the central area of the physiographic basin.

Of the two sites drilled in the North Aoba Basin, Site 832 (lithostratigraphic Units VI and VII, 866-1101 mbsf, Hole 832B) revealed the oldest sedimentary rocks, which are composed of volcaniclastic debris-flow deposits, turbidites, and some hemipelagic sediment (Fig. 11; Collot, Greene, Stokking, et al., 1992; Goud Collins, this volume). Calc-alkaline lavas recovered from lithostratigraphic Unit VII are similar to calk-alkaline andesites found on Espiritu Santo (Hasenaka et al., this volume). Dates obtained from microfossils in sedimentary rocks of Unit VII ranged from early to middle Miocene, but the microfossils are thought to be reworked (Staerker, this volume; Goud Collins, this volume). However, microfossils give a late Miocene age for sedimentary rocks of Unit VI. A basaltic clast was dated at $5.66 \pm 0.85 \mathrm{Ma}$ (Rex, this volume), giving an age of no earlier than latest Miocene for the strata of lithostratigraphic Unit VII (Site 832), but this seems too young in light of the microfossil assemblage and probably reflects Ar loss.

Perembo (this volume) states that at Site 828 over 35 biostratigraphic events were determined and 9 planktonic foraminiferal zones established and that this stratigraphy can be correlated with Site 832 stratigraphy. He found that the age succession at Site 828 extends from the earliest Miocene (N8) to late Pliocene (N22). Basal N8 occurs 1008.6-971.8 mbsf with an unconformity at $971.8 \mathrm{mbsf}$ (Site 832) incorporating N9 through N13 (Perembo, this volume).

Erosional and buttress unconformities in the Central Basins indicate that vertical tectonism elevated and depressed local horsts and grabens. Onset of the DEZ collision resulted in the uplift of the Western Belt of islands that is reflected in a buttress unconformity within the Central Basins. A major buttress unconformity imaged in seismic reflection profiles in the North Aoba Basin (Greene, Macfarlane, Johnson, and Crawford, 1988; Greene et al., this volume) is thought to represent the approximate time (early Pleistocene) of collision of the DEZ with the arc, and thus was a major objective for drilling at Site 832 . Here, penetration of the unconformity was made near 700 mbsf. The timing of the uplift and formation of the unconformity are not well constrained, but biostratigraphic analyses of cores from Hole 832B indicate that the hiatus between lithostratigraphic Units IV and $\mathrm{V}$ spans an age of from less than 1.89 Ma to more than $1.58 \mathrm{Ma}$ (or $0.31 \mathrm{~m} . \mathrm{y}$.) between 654 and $702 \mathrm{mbsf}$, an early Pleistocene age. This correlates with the early to middle Pleistocene or older age given to the oldest thrust fault in the NDR-arc collision zone (Staerker, this volume). Zhao et al. (this volume) report that above the unconformity numerous slump structures have disturbed primary depositional remnant magnetizations and a reliable magnetostratigraphy is not possi-

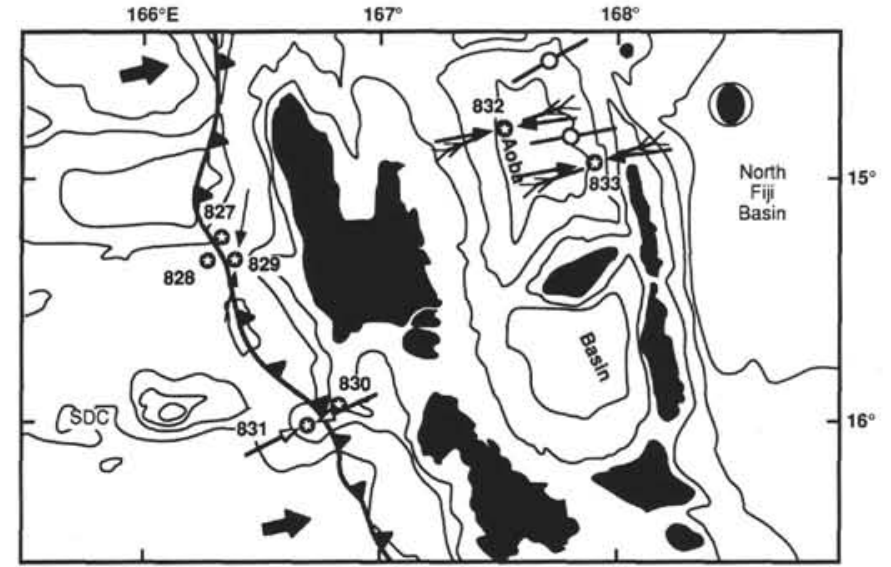

Figure 9. Breakouts and other structural stresses observed in drill holes and interpreted from seismicity data (Louat and Pelletier, 1989). These measurements indicate nearly orthogonal collision. Starred dots are drill sites; double tailed lines indicate vertically induced fractures; thin lines with arrows give orientation of stress from breakouts (Chabernaud, this volume); open arrowed line give orientation of stress from breakouts (Krammer et al., this volume); open circled lines give orientation of stress from seismic studies (Louat and Pelletier, 1989); beach ball indicates thrust motion from average focal mechanism solutions (Louat and Pelletier, 1989); barbed line indicates seafloor trace of subduction zone; filled large arrows indicate direction of plate motion (from Krammer et al., this volume).

ble from 150-700 mbsf and the Brunhes/Matuyama boundary was not identified at Site 832. Reliable magnetostratigraphy and biostratigraphic data recorded from $700-825$ mbsf indicate sediments in this interval were deposited from late Miocene (Chron 5) to the Pliocene/ Pleistocene boundary (Zhao et al., this volume).

Basaltic sills drilled at Site 833B have striking compositional similarities, despite their greater age, to the high-Ti series lavas described by Eggins (1993) from Aoba volcano. They are probably associated with the transition from Eastern Belt magmatism to the generally higher-K Central Chain magmatism and have provided key evidence for the pre-collision isotopic identity of arc magmatism in the central New Hebrides Island Arc (Briqueu et al., this volume).

Volcanic activity from the late Pliocene onward was concentrated along the Central Chain and that collision of the DEZ modified distribution of volcanoes in the central part of the arc (Crawford et al., 1988). Isotopic data indicate that the DEZ collision had a profound effect on the composition of erupted magmas (Briqueu et al., this volume). Post-collision magmas carry an unusual 'enriched' component indicating derivation from a very different isotopic reservoir than the pre-collision arc magmas and lavas currently erupted away from the collision zone. Interestingly, the collision has had almost no effect on the major and trace element compositions of lavas (Hasenaka et al., this volume), with pre-collision sills and clasts having an essentially identical range of compositions as the post-collision magmas.

At Hole 833B Zhao et al. (this volume) recognized the Brunhes/ Matuyama boundary and Jaramillo subchron from $650-700 \mathrm{mbsf}$ and tentatively identified the Kaena and Mammoth subchrons. Magnetostratigraphy at Site 833 implies a sedimentation rate of $10 \mathrm{~cm} / \mathrm{ky}$ during middle Pliocene in contrast to a low sedimentation rate at Site 832 of $1.5 \mathrm{~cm} / \mathrm{ky}$ for the same period (Zhao et al. this volume).

During the Quaternary, when the Western and Eastern belts in the central part of the New Hebrides Island Arc were being uplifted, the Central Basins evolved from open-ocean to more restrictive enclosed conditions. Due primarily to tectonic activity, depths of the basins fluctuated greatly. Akimoto (this volume), on the basis of analyses of large benthic foraminifers, shows that during the early Pleistocene the paleodepths of the North Aoba Basin subsided 500-1500 m, ultimately reaching abyssal depths of $4000-4500 \mathrm{~m}$ before shallowing. 


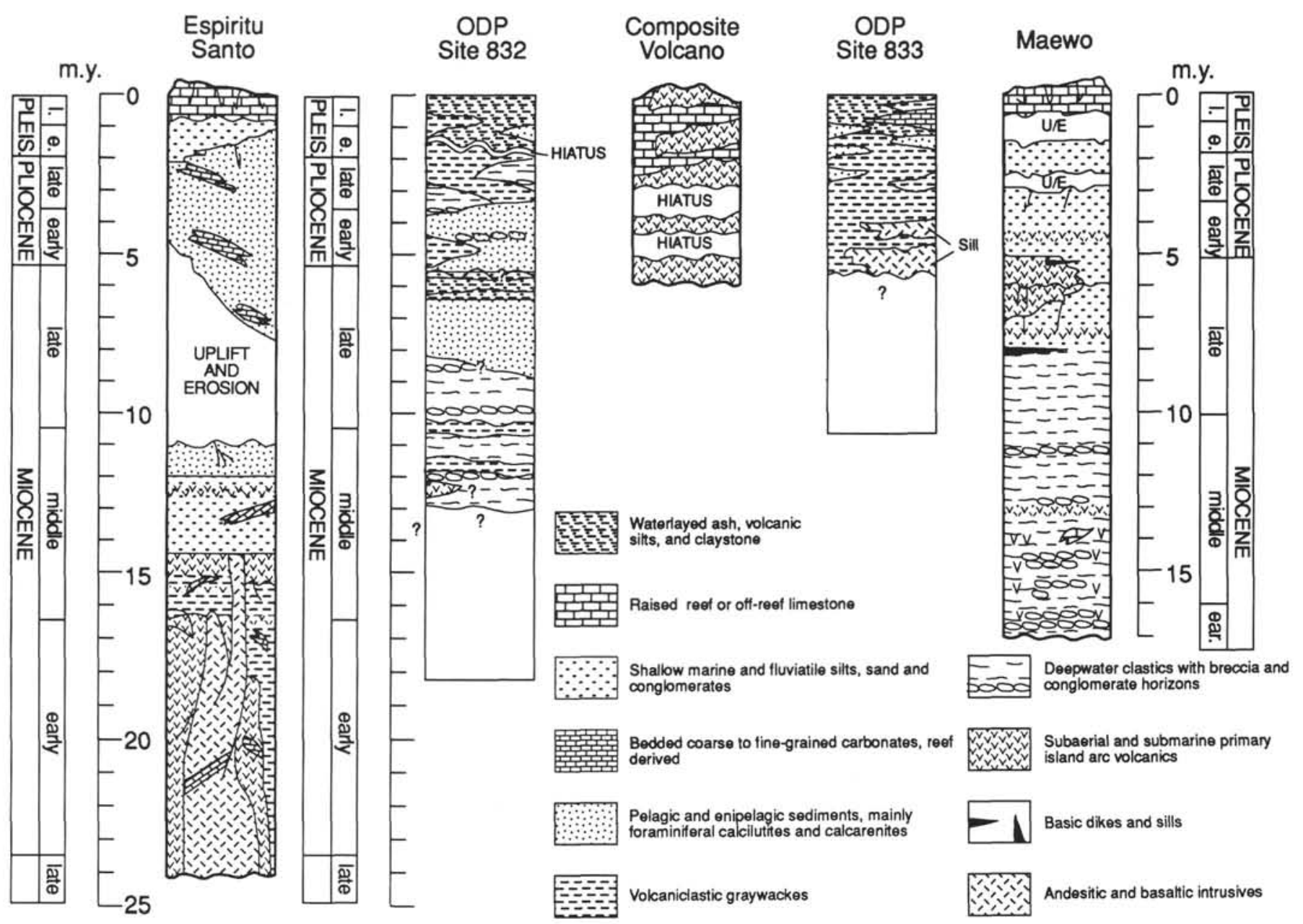

Figure 10. Correlation of stratigraphic columns in the North Aoba Basin based on seismic and drill data collected during Leg 134 showing relationship of island and basin stratigraphy (modified from Greene, Macfarlane, Johnson, and Crawford, 1988, and Fisher et al., this volume).

During late Pleistocene, the North Aoba Basin paleodepths changed from abyssal depths $(\sim 4000 \mathrm{~m})$ to the present depth of $3100 \mathrm{~m}$ (Akimoto, this volume).

Goud Collins (this volume) states that in the late Pleistocene sedimentation was dominated by volcanic ash flows as the Central Chain volcanoes built depositional aprons. Effusive ash falls also occurred, and this, along with hemipelagic deposition rapidly filled the North Aoba Basin to its present level.

\section{Basin Fluids}

Martin (this volume) reports that in the intra-arc North Aoba Basin alteration of volcanic ash to clay minerals and zeolites forms a $\mathrm{CaCl}$ brine, perhaps in less than 1-3 m.y. He states that the brine is a product of an exchange of $\mathrm{Ca}$ for $\mathrm{Na}, \mathrm{K}$, and $\mathrm{Mg}$ and an increase in $\mathrm{Cl}$ concentrations to a maximum of $1241 \mathrm{mM}$. Although the $\mathrm{Cl}$ increase is thought to be the result of the transfer of $\mathrm{H}_{2} \mathrm{O}$ from the pore fluid into authigenic minerals, the water mass balances, $\mathrm{O}-\mathrm{Cl}$ correlations and $\mathrm{Br} / \mathrm{Cl}$ ratios suggest that there is a source of $\mathrm{Cl}$ in the sediment as well. Based on concentration profiles, it appears that $\mathrm{Li}$ is transferred from the fluid to solid phase at a depth of $300 \mathrm{mbsf}$, but at greater depths is transferred from the solid to fluid phase, at temperatures possibly as low as $25^{\circ} \mathrm{C}$.

\section{Hydrocarbons Source Rocks Analyses}

Extensive work was undertaken previously to ODP Leg 134 to assess the resource potential of Vanuatu (Greene, Macfarlane, and Wong, 1988). Previous hydrocarbon source rock analyses, from on- shore (island) outcrop samples, indicated from Rock-Eval pyrolysis and reflected-light microscopy on separated organic matter, that organic matter is poor in hydrogen (dominantly Kerogen type III, which is a chemical type that does not yield liquid hydrocarbons), but may have a limited potential for generating gas (Buchbinder and Halley, 1988). Nevertheless, these authors stated that both Rock-Eval pyrolysis and vitrinite-reflectance analyses indicated thermally mature organic matter. To extend this study, 19 rocks samples taken from cores in the North Aoba Basin (Sites 832 and 833) were submitted to the Branch of Petroleum Geology of the U. S. Geological Survey for Rock-Eval pyrolysis. The result of this study indicate that all samples yielded low values of organic content (Table 1; Les Magoon and Chuck Threlkeld, written comm., 1992).

\section{CONCLUSIONS}

Analyses of cores recovered by Leg 134 drilling resulted in the following conclusions:

1. Forearc deformation is associated with two different positive topographic features (the North d'Entrecasteaux Ridge and South d'Entrecasteaux Chain) and their collision with the arc is distinct and different. The collision and subduction of the North d'Entrecasteaux Ridge results in offscraping of ridge material and plating the forearc with thrust sheets (flakes) as well as distinct forearc uplift as indicated by Wousi Bank. In contrast, the South d'Entrecasteaux Chain is a serrated feature resulting in intermittent collision and subduction of sea- 


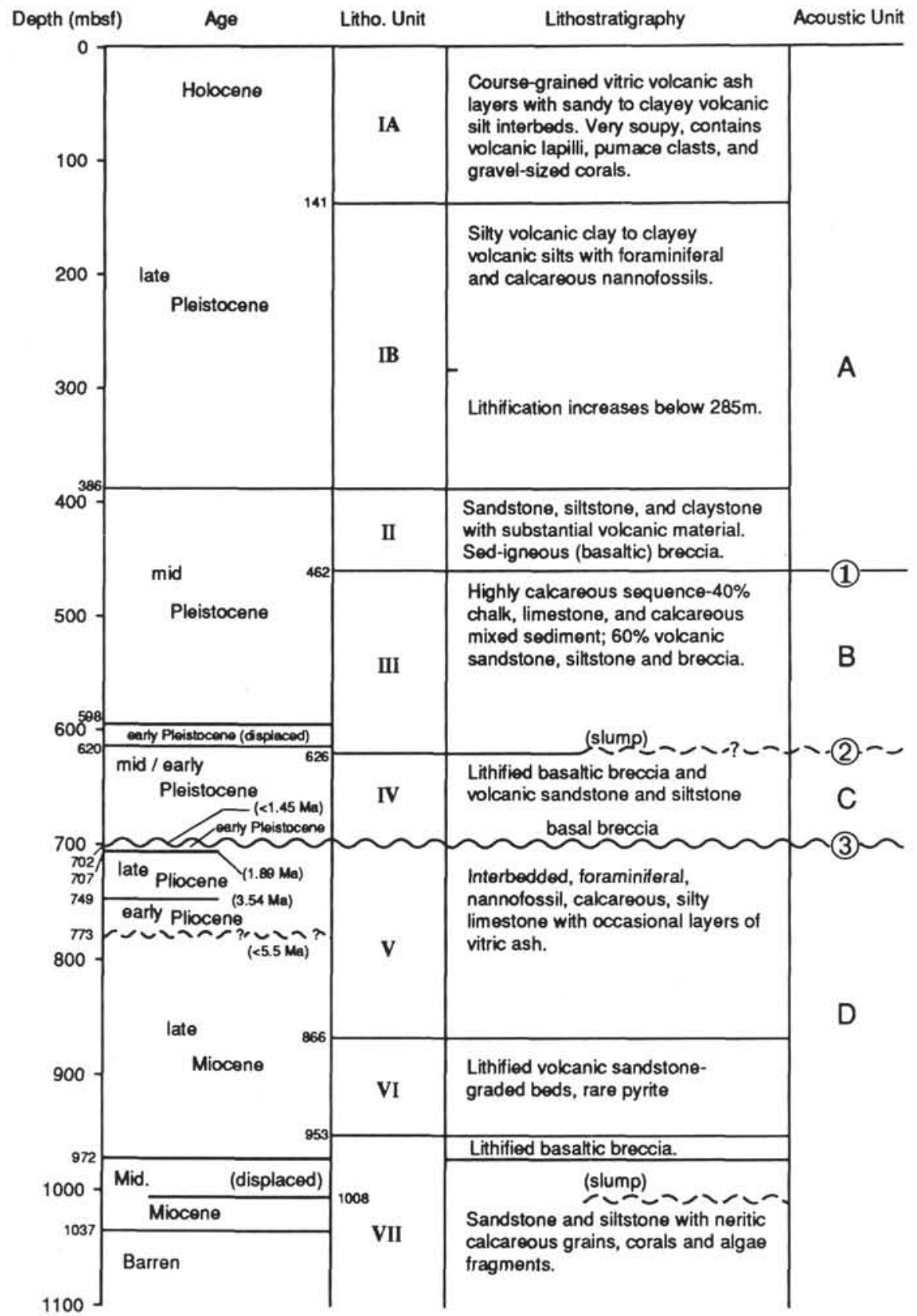

Figure 11. Lithologic column relating age and lithostratigraphy at Site 832 with acoustic units interpreted from seismic reflection profiles collected during Leg 134 in the North Aoba Basin (modified from Greene, Macfarlane, Johnson, and Crawford, 1988, and Fisher et al., this volume).

mounts. The collision of the Bougainville Guyot has indented the forearc and appears to be causing forearc shortening through thrust faulting.

2. The d'Entrecasteaux Zone is an Eocene subduction/obduction complex with a distinct volcanic arc.

3. Offscraped sedimentary rock and surficial volcanic basement rocks of the North d'Entrecasteaux Ridge are being underplated to the New Hebrides Island forearc.

4. Dewatering is occurring in the North d'Entrecasteaux Ridge accretionary wedge, and the wedge is dryer than other previously studied accretionary wedges, such as the Barbados. This could be the result of less sediment being subducted at the New Hebrides compared to the Barbados.

5. The Quaternary relative convergence rate appears to be as high as 14 to $16 \mathrm{~cm} / \mathrm{yr}$ between the Australia-India Plate and the North Fiji Basin microplates.
6. The timing of initial d'Entrecasteaux Zone collision occurred at $\sim 3 \mathrm{Ma}$ at the latitude of Epi Island and fixed the impact of the North d'Entrecasteaux Ridge upon Espiritu Santo Island at early Pleistocene time (between 1.89 and $1.58 \mathrm{Ma}$ ).

7. The northward migration rate of the d'Entrecasteaux Zone along the arc is established at $\sim 2$ to $4 \mathrm{~cm} / \mathrm{yr}$ based on the newly determined Quaternary relative convergence rate.

\section{ACKNOWLEDGMENTS}

We wish to acknowledge the support and assistance of the ODP editorial staff in the review of this manuscript. This paper has benefited from the reviews of Tracy Vallier, Ray Wells, and Laura Stokking; we sincerely appreciate their assistance. Figures were prepared by Lynn McMasters and the manuscript was typed by Susan Kalb. 
Preparation of illustrations was financially supported by USSAC Award \#8849.7795.

\section{REFERENCES}

American Association of Petroleum Geologists, 1985. Plate tectonic map of the circum-Pacific region, southwest quadrant. Circum-Pacific Map Project (scale 1:10,000,000).

Auzende, J.-M., Lafoy, Y., and Marsset, B., 1988. Recent geodynamic evolution of the North Fiji Basin (Southwest Pacific). Geology, 16:925-929.

Buchbinder, B., and Halley, R.B., 1988. Source-rock evaluation of outcrop samples from Vanuatu (Malakula, Espiritu Santo, and Pentecost). In Greene, H.G., and Wong, F.L. (Eds.), Geology and Offshore Resources of Pacific Island Arcs-Vanuatu Region. Circum-Pac. Counc. Energy Miner. Resour., Earth Sci. Ser., 8:255-266.

Burne, R.V., Collot, J.-Y., and Daniel, J., 1988. Superficial structures and stress regimes of the downgoing plate associated with subduction-collision in the Central New Hebrides Arc (Vanuatu). In Greene, H.G., and Wong, F.L. (Eds.), Geology and Offshore Resources of Pacific Island Arcs-Vanuatu Region. Circum-Pac. Counc. Energy Miner. Resour., Earth Sci. Ser., 8:357-376.

Carney, J.N., and Macfarlane, A., 1977. Volcano-tectonic events and pre-Pliocene crustal extension in the New Hebrides. Int. Symp. on Geodynamics in South-west Pacific, Noumea, New Caledonia, 1976. Paris (Editions Technip), 91-104.

- 1978. Lower to middle Miocene sediments on Maewo, New Hebrides, and their relevance to the development of the Outer Melanesian Arc system. Aust. Soc. Explor. Geophys. Bull., 9:123-130.

, 1980. A sedimentary basin in the central New Hebrides Arc. Tech. Bull.-U.N. Econ. Soc. Comm. Asia Pac., Comm. Co-ord. Jt. Prospect Miner. Resour. South Pac. Offshore Areas, 3:109-120.

Charvis, P., and Pelletier, B., 1989. The northern New Hebrides back-arc troughs: history and relation with the North Fiji basin. Tectonophysics, 170:259-277.

Chase, C.G., 1971. Tectonic history of the Fiji Plateau. Geol. Soc. Am. Bull., 82:3087-3110.

Collot, J.-Y., Daniel, J., and Burne, R.V., 1985. Recent tectonics associated with the subduction/collision of the d'Entrecasteaux zone in the central New Hebrides. Tectonophysics, 112:325-356.

Collot, J.-Y., and Fisher, M.A., 1988. Crustal structure from gravity data of a collision zone in the central New Hebrides Island Arc. In Greene, H.G., and Wong, F.L. (Eds.), Geology and Offshore Resources of Pacific Island Arcs-Vanuatu Region. Circum-Pac. Counc. Energy Miner. Resour., Earth Sci. Ser., 8:125-140.

1991. The collision zone between the North d'Entrecasteaux Ridge and the New Hebrides island arc. Part 1: Sea Beam morphology and shallow structure. J. Geophys. Res., 96:4457-4478.

Collot, J.-Y., Greene, H.G., Stokking, L.B., et al., 1992. Proc. ODP, Init. Repts., 134: College Station, TX (Ocean Drilling Program).

Collot, J.-Y., Lallemand, S., Pelletier, B., Eissen, J.-P., Glaçon, G., Fisher, M.A., Greene, H.G., Boulin, J., Daniel, J., and Monzier, M., 1992. Geology of the d'Entrecasteaux-New Hebrides Arc collision zone: results from a deep submersible survey. Tectonophysics, 212:213-241.

Collot, J.-Y., Pelletier, B., Boulin, J., Daniel, J., Eissen, J.P., Fisher, M.A., Greene, H.G., Lallemand, S., and Monzier, M., 1989. Premiers résultats des plongees de la campagnee SUBPSO1 dans la zone de collision des rides d'Entrecasteaux et de l'arc des Nouvelles Hébrides. C. R. Acad. Sci. Ser. 2, 309:1947-1954.

Crawford, A.J., Greene, H.G., and Exon, N.F., 1988. Geology, petrology and geochemistry of submarine volcanoes around Epi Island, New Hebrides Island Arc. In Greene, H.G., and Wong, F.L. (Eds.), Geology and Offshore Resources of Pacific Island Arcs-Vanuatu Region. Circum-Pac. Counc. Energy Miner. Resour., Earth Sci. Ser., 8:301-327.

Daniel, J., Collot, J.-Y., Monzier, M., Pelletier, B., Butscher, J., Deplus, C., Dubois, J., Gérard, M., Maillet, P., Monjaret, M.C., Récy, J., Renard, V., Rigolot, P., and Temakon, S.J., 1986. Subduction et collision le long de l'arc des Nouvelles-Hébrides (Vanuatu): résultats préliminaires de la campagne SEAPSO (Leg 1). C. R. Acad. Sci. Ser. 2, 303:805-810.

\footnotetext{
"Abbreviations for names of organizations and publications in ODP reference lists follow the style given in Chemical Abstracts Service Source Index (published by American Chemical Society).
}

Daniel, J., Gérard, M., Mauffret, A., Boulanger, D., Cautin, B., Collot, J.-Y., Durand, J., Fisher, M., Greene, H.G., Michaux, P., Pelletier, B., Pezzimenti, A., Renard, V., Schaming, M., and Tissot, J.D., 1989. Déformation compressive d'un bassin intra-arc dans un contexte de collision ride/arc: le bassin d'Aoba, arc des Nouvelles-Hébrides. C. R. Acad. Sci. Ser. 2, 308:239-245.

Daniel, J., Jouannic, C., Larue, B., and Récy, J., 1977. Interpretation of d'Entrecasteaux zone (north of New Caledonia). Int. Symp. on Geodynamics in South-west Pacific, Noumea, New Caledonia, 1976. Paris (Editions Technip), 117-124.

Dubois, J., Deplus, C., Diament, M., Daniel, J., and Collot, J.-Y., 1988. Subduction of the Bougainville seamount (Vanuatu): mechanical and geodynamic implications. Tectonophysics, 149:111-119.

Dubois, J., Dugas, F., Lapouille, A., and Louat, R., 1975. Fossés d'effondrement en arrière de l'arc des Nouvelles-Hébrides-mécanismes proposés. Rev. Geogr. Phys. Geol. Dyn., 17:73-94.

1978. The troughs at the rear of the New Hebrides island arc: possible mechanisms of formation. Can. J. Earth Sci., 15:351-360.

Eggins, S.M., 1993. Origin and differentiation of picritic arc lavas from Aoba (Ambae), Vanuatu. Contrib. Mineral. Petrol., 114:79-100.

Falvey, D.A., and Greene, H.G., 1988. Origin and evolution of the sedimentary basins of the New Hebrides Arc. In Greene, H.G., and Wong, F.L. (Eds.), Geology and Offshore Resources of Pacific Island Arcs-Vanuatu Region. Circum-Pac. Counc. Energy Miner. Resour., Earth Sci. Ser., 8:413-442.

Fisher, M.A., 1986. Tectonic processes at the collision of the d'Entrecasteaux zone and the New Hebrides island arc. J. Geophys. Res., 91:10470-10486.

Fisher, M.A., Collot, J.-Y., and Geist, E.L., 1991. The collision zone between the North d'Entrecasteaux Ridge and the New Hebrides Island Arc. Part 2: structure from multichannel seismic data. J. Geophys. Res., 96:4479-4495.

Fisher, M.A., Collot, J.-Y., and Smith, G.L., 1986. Possible causes for structural variation where the New Hebrides island arc and the d'Entrecasteaux zone collide. Geology, 14:951-954.

Fisher, M.A., Falvey, D.A., and Smith, G.L., 1988. Seismic stratigraphy of the summit basins of the New Hebrides island arc. In Greene, H.G., and Wong, F.L. (Eds.), Geology and Offshore Resources of Pacific Island ArcsVanuatu Region. Circum-Pac. Counc. Energy Miner. Resour., Earth Sci. Ser., 8:201-223.

Gieskes, J.M., Blanc, G., Vrolijk, P., Elderfield, H., and Barnes, R., 1990. Interstitial water chemistry-major constituents. In Moore, J.C., Mascle, A., et al., Proc. ODP, Sci. Results, 110: College Station, TX (Ocean Drilling Program), 155-178.

Gieskes, J.M., Vrolijk, P., and Blanc, G., 1990. Hydrogeochemistry of the Northern Barbados Accretionary Complex Transect: ODP Leg 110. J. Geophys. Res., 95:8809-8818.

Gill, J.B., and Gorton, M.P., 1973. A proposed geological and geochemical history of eastern Melanesia. In Coleman, P.J. (Ed.), The Western Pacific: Island Arcs, Marginal Seas and Geochemistry: Perth (Univ. of Western Australia Press), 543-566.

Greene, H.G., Collot, J.-Y., Pelletier, B., and Lallemand, S., 1992. Observation of forearc seafloor deformation along the north d'Entrecasteaux RidgeNew Hebrides Island Arc collision zone from Nautile submersible. In Collot, J.-Y., Greene, H.G., Stokking, L.B., et al., Proc. ODP, Init. Repts., 134: College Station, TX (Ocean Drilling Program), 43-53.

Greene, H.G., and Johnson, D.P., 1988. Geology of the central basin region of the New Hebrides arc inferred from single-channel seismic-refraction data. In Greene, H.G., and Wong, F.L. (Eds.), Geology and Offshore Resources of Pacific Island Arcs-Vanuatu Region. Circum-Pac. Counc. Energy Miner. Resour., Earth Sci. Ser., 8:117-199.

Greene, H.G., Macfarlane, A., Johnson, D.A., and Crawford, A.J., 1988. Structure and tectonics of the central New Hebrides Arc. In Greene, H.G. and Wong, F.L. (Eds.), Geology and Offshore Resources of Pacific Island Arcs_-Vanuatu Region. Circum-Pac. Counc. Energy Miner. Resour., Earth Sci. Ser., 8:377-412.

Greene, H.G., Macfarlane, A., and Wong, F.L., 1988. Geology and offshore resources of Vanuatu-introduction and summary. In Greene, H.G., and Wong, F.L. (Eds.), Geology and Offshore Resources of Pacific Island Arcs-Vanuatu Region. Circum-Pac. Counc. Energy Miner. Resour., Earth Sci. Ser., 8:1-25.

Hanus, V., and Vanek, J., 1983. Deep structure of the Vanuatu (New Hebrides) islands arc: intermediate depth collision of subducted lithospheric plates. N.Z. J. Geol. Geophys., 26:133-154.

Holmes, M.L., 1988. Seismic refraction measurements in the summit basins of the New Hebrides Arc. In Greene, H.G., and Wong, F.L. (Eds.), Geology 
and Offshore Resources of Pacific Island Arcs-Vanuatu Region. CircumPac. Counc. Energy Miner. Resour., Earth Sci. Ser., 8:163-176.

Johnson, D.P., Belford, D.J., Carter, A.N., and Crawford, A.J., 1988. Petrology and age of dredge samples collected in the Central Basin, Vanuatu. In Greene, H.G., and Wong, F.L. (Eds.), Geology and Offshore Resources of Pacific Island Arcs-Vanuatu Region. Circum-Pac. Counc. Energy Miner Resour., Earth Sci. Ser., 8:141-162.

Karig, D.E., and Mammerickx, J., 1972. Tectonic framework of the New Hebrides island arc. Mar. Geol., 12:187-205.

Katz, H.R., 1988. Offshore geology of Vanuatu-previous work. In Greene, H.G., and Wong, F.L. (Eds.), Geology and Offshore Resources of Pacific Island Arcs-Vanuatu Region. Circum-Pac. Counc. Energy Miner. Resour., Earth Sci. Ser., 8:93-122.

Kroenke, L.W., 1984. Introduction. In Kroenke, L.W. (Ed.), Cenozoic Tectonic Development of the Southwest Pacific. Tech. Bull--U. N. Econ. Soc. Comm. Asia Pac., Comm. Co-ord. Jt. Prospect Miner. Resour. South Pac. Offshore Areas, 6:1-11.

Kroenke, L.W., Jouannic, C., and Woodward, P. (Compilers), 1983. Bathymetry of the southwest Pacific, Chart 1: Geophysical Atlas of the Southwest Pacific. Scale 1:6,442,192 at $0^{\circ}$, Suva, Fiji. U.N. Econ. Soc. Comm. Asia. Pac., CCOP/SOPAC Tech. Secretariat.

Louat, R., Hamburger, M., and Monzier, M., 1988. Shallow and intermediatedepth seismicity in the New Hebrides Arc: constraints on the subduction process. In Greene, H.G., and Wong, F.L. (Eds.), Geology and Offshore Resources of Pacific Island Arcs-Vanuatu Region. Circum-Pac. Counc. Energy Miner. Resour., Earth Sci. Ser., 8:329-356.

Louat, R., and Pelletier, B., 1989. Seismotectonics and present-day relative plate motions in the New Hebrides-North Fiji basin region. Tectonophysics, 167:41-55.

Luyendyk, B.P., Bryan, W.B., and Jezek, P.A., 1974. Shallow structure of the New Hebrides island arc. Geol. Soc. Am. Bull., 85:1287-1300.

Macfarlane, A., Carney, J.N., Crawford, A.J., and Greene, H.G., 1988. Vanuatua review of the onshore geology. In Greene, H.G., and Wong, F.L. (Eds.), Geology and Offshore Resources of Pacific Island Arcs-Vanuatu Region. Circum-Pac. Counc. Energy Miner. Resour., Earth Sci. Ser., 8:45-91.

Maillet, P., Monzier, M., Selo, M., and Storzer, D., 1983. The d'Entrecasteaux zone (southwest Pacific): a petrological and geochronological reappraisal. Mar. Geol., 53:179-197.

Mascle, A., Moore, J.C., et al., 1988. Proc. ODP, Init. Repts., 110: College Station, TX (Ocean Drilling Program).

Musgrave, R.J., and Firth, J.V., 1993. Magnitude and timing of New Hebrides Arc rotation following spreading propagation in the North Fiji Basin: paleomagnetic evidence from Nendo, Solomon Island. In Wheller, G.E. (Ed.), Islands and Basins: Correlation and Comparison of Onshore and Offshore Geology. Abstracts, Sci. Tect. and Resour. (STAR), 22nd SOPAC Session, So. Pac. Appl. Geosci. Commis. (SOPAC) Misc. Rep., 159:9-10.
Pascal, G., Isacks, B.L., Barazangi, M., and Dubois, J., 1978. Precise relocations of earthquakes, and seismotectonics of the New Hebrides island arc. J. Geophys. Res., 83:4957-4973.

Price, R.C., Maillet, P., and Johnson, D.P., 1993. Interpretation of GLORIA side-scan sonar imagery for the Coriolis Troughs of the New Hebrides backarc. Geo-Mar. Lett., 13:71-81.

Recy, J., Charvis, P., Ruellan, E., Monjaret, M.C., Gerard, M., Auclair, G., Baldassari, C., Boirat, J.M., Brown, G.R., Butscher, J., Collot, J.-Y., Daniel, J., Louat, R., Monzier, M., and Pontise, B., 1986. Tectonique et volcanisme sous-marin a l'arrière de l'arc des Nouvelles-Hébrides (Vanuatu, Pacifique sud-ouest): résultats préliminaries de la compagne SEAPSO Leg II du N/O Jean Charcot. C. R. Acad. Sci. Ser. 2, 303:685-690.

Recy, J., Pelletier, B., Charvis, P., Gerard, M., Monjaret, M.-C., and Maillet, P., 1990. Structure, age, et origine de fossés arrière-arc de NouvellesHebrides (Sud-Ouest Pacifique). Oceanol. Acta, spec. vol., 10:165-182.

Shipboard Scientific Party, 1975. Site 286. In Andrews, J.E., Packham, G., et al., Init. Repts. DSDP, 30: Washington (U.S. Govt. Printing Office), 69-131.

Taylor, F.W., Frohlich, C., Lecolle, J., and Strecker, M.R., 1987. Analysis of partially emerged corals and reef terraces in the central Vanuatu Arc: comparison of contemporary coseismic and nonseismic with Quaternary vertical movements. J. Geophys. Res., 92:4905-4933.

Taylor, F.W., Isacks, B.L., Jouannic, C., Bloom, A.L., and Dubois, J., 1980 Coseismic and Quaternary vertical tectonic movements, Santo and Malekula Islands, New Hebrides island arc. J. Geophys. Res., 85:5367-5381. [Correction in J. Geophys. Res., 86:6066.]

Taylor, F.W., Jouannic, C., and Bloom, A.L., 1985. Quaternary uplift of the Torres Islands, northern New Hebrides frontal arc: comparison with Santo and Malekula Islands, central New Hebrides frontal arc. J. Geol., 93:419438

Tiffin, D.L., Clarke, J.E.H., Jarvis, P.J., Hill, P., Huggelt, Q., Parson, L., Price, R.C., and Shipboard Party, 1990. CCOP/SOPAC GLORIA survey, Port Vila-Apia-Port Vila on HMAS Cook. SOPAC Cruise Rep., 130.

Weissel, J.K., Watts, A.B., and Lapouille, A., 1982. Evidence for late Paleocene to late Eocene sea floor in the southern New Hebrides Basin. Tectonophysics, 87:243-251.

Wells, R.E., 1989. The oceanic basalt basement of the Solomon Islands Arc and its relationship to the Ontong-Java Plateau: insights from Cenozoic plate motion models. In Vedder, J.G., and Bruns, T.R. Geology and Offshore Resources of Pacific Island Arcs-Solomon Islands and Bougainville, Papua New Guinea Regions. Circum-Pac. Counc. Energy Miner. Resour., Earth Sci. Ser., 12:7-22.

Date of initial receipt: 8 December 1993

Date of acceptance: 3 January 1994

Ms 134SR-040

Table 1. Table showing values derived from Rock-Eval pyrolysis of 19 rock samples taken from cores at Sites 832 and 833 (C. Threlkeld, written comm., 1992).

\begin{tabular}{ccccccccrr}
\hline Sample & $\begin{array}{c}\text { Interval } \\
(\mathrm{cm})\end{array}$ & $\begin{array}{c}\text { Temperature } \\
\text { (max) }\end{array}$ & $\mathrm{S}_{1}$ & $\mathrm{~S}_{2}$ & $\mathrm{~S}_{3}$ & $\mathrm{~S}_{2 / 3}$ & $\mathrm{TOC}$ & $\mathrm{HI}$ & OI \\
\hline 134-832B-09R-01 & $008-010$ & 592 & 0.08 & 0.69 & 2.42 & 0.28 & 0.13 & 530 & 1861 \\
134-832B-17R-03 & $054-056$ & 580 & 0.21 & 1.61 & 3.46 & 0.46 & 0.31 & 519 & 1116 \\
134-832B-18R-03 & $078-080$ & 527 & 0.05 & 0.32 & 1.23 & 0.26 & 0.06 & 533 & 2050 \\
134-832B-19R-02 & $022-024$ & 584 & 0.02 & 0.68 & 0.29 & 2.34 & 0.07 & 971 & 414 \\
134-832B-29R-03 & $012-013$ & 593 & 0.28 & 1.05 & 0.49 & 2.14 & 0.11 & 954 & 445 \\
134-832B-30R-05 & $057-058$ & 574 & 0.18 & 1.75 & 2.49 & 0.7 & 0.32 & 546 & 778 \\
134-832B-31R-03 & $127-129$ & 578 & 0.08 & 0.83 & 4.36 & 0.19 & 0.34 & 244 & 1282 \\
134-832B-42R-02 & $110-112$ & 582 & 0.05 & 0.51 & 2.17 & 0.23 & 0.12 & 425 & 1808 \\
134-832B-47R-01 & $040-041$ & 588 & 0.07 & 0.79 & 2.26 & 0.34 & 0.12 & 658 & 1883 \\
134-832B-61R-05 & $040-042$ & 589 & 0.12 & 0.55 & 1.45 & 0.37 & 0.09 & 611 & 1611 \\
134-832B-68R-CC & $017-018$ & 412 & 0.3 & 3.04 & 10.74 & 0.28 & 3.74 & 81 & 287 \\
134-833A-02H-03 & $145-150$ & 445 & 0.01 & 0.39 & 4.12 & 0.09 & 0.12 & 325 & 3433 \\
134-833A-03H-02 & $122-124$ & 400 & 0.1 & 0.7 & 3.45 & 0.2 & 0.18 & 388 & 1916 \\
134-833A-26X-02 & $053-057$ & 593 & 0.16 & 0.77 & 2.75 & 0.28 & 0.13 & 592 & 2115 \\
134-833B-29R-01 & $040-042$ & 360 & 0.1 & 0.39 & 2.1 & 0.18 & 0.12 & 325 & 1750 \\
134-833B-76R-03 & $010-011$ & 325 & 0.19 & 0.74 & 0.94 & 0.78 & 0.14 & 528 & 671 \\
134-833B-77R-04 & $005-006$ & 388 & 0.07 & 0.24 & 1.37 & 0.17 & 0.1 & 240 & 1370 \\
134-833B-78R-C1 & $006-008$ & 343 & 0.07 & 0.33 & 0.94 & 0.35 & 0.09 & 366 & 1044 \\
134-833B-88R-01 & $105-106$ & 526 & 0 & 0.13 & 0.53 & 0.24 & 0.14 & 92 & 378 \\
\hline
\end{tabular}

Note: $S_{1}$ is amount of free or absorbed hydrocarbons; $S_{2}$ is amount of hydrocarbons or hydrocarbon-like compounds generated by pyrolysis of kerogen; $S_{3}$ is amount of oxygen-containing volatiles (i.e., carbon dioxide and water) generated by pyrolysis of kerogen; TOC is total organic carbon; $\mathrm{HI}$ is hydrogen index; $\mathrm{OI}$ is oxygen index. 